\title{
Petar Bakić - biskup i vlastelin (1716. - 1749.)
}

\author{
MARIN SRAKIĆ*
}

\begin{abstract}
UDK: 27-726.2 (497.5 Đakovo) *929 Bakić, P. • Izvorni znanstveni rad Primljeno: 15. veljače 2017. • Prihvaćeno: 8. svibnja 2017.
\end{abstract}

Sažetak: Prije 300 godina, tj. 1716. godine, bosanskim ili dakovačkim biskupom imenovan je Petar Bakić, svećenik Splitske (nad)biskupije, revni misionar panonsko-slavonskih krajeva, »izabrani biskup srijemski« (electus Sirmiensis). Kad je Bakić nastupio na svoju službu, u biskupiji su još bili vidljivi tragovi turskoga razaranja. Zato se on svojski dao na uređenje biskupije počevši od dogradnje stolne crkve, preko uređenja nekih župnih crkava, nabavljanja crkvenoga namještaja itd. Biskupija je bila malena, svega četiri župe o kojima su se pastoralno skrbili franjevci Provincije Bosne Srebrene. Njegovim dolaskom započinje i organizirana gospodarska melioracija na svim područjima kao što su vinogradarstvo, ratarstvo, stočarstvo itd. Zbog svoje žestoke naravi biskup je često dolazio u sukob sa svojom okolinom: franjevcima, Ko-

${ }^{*}$ Mons. dr. sc.

Marin Srakić, đakovačko-osječki nadbiskup u miru, Strossmayerov $\operatorname{trg} 6$,

31400 Đakovo, Hrvatska, marin.srakic@djos.hr mornim nadzorništvom u Osijeku i podanicima. Franjevci su branili svoja pastoralna prava i pozivali se na svoje zasluge, a vojne vlasti vrijeđale su na sve moguće načine Bakićeva prava kao vlastelina, ali i kao biskupa, a podanici su se žalili na razna davanja i teške radove na uređenju vlastelinstva. Nakon bezbroj tužbi i optužbi s jedne i druge strane Ratno vijeće pod predsjedanjem Eugena Savojskoga, a uz suglasnost carskoga dvora, stavilo je biskupa Petra Bakića pod sekvestar, zabranivši mu ulazak na područje njegove biskupije. Mnogo toga što je on u svojoj revnosti zasadio i izgradio oštećeno je ili uništeno za vrijeme njegove odsutnosti. Kad se pomilovanjem carice Marije Terezije vratio u biskupiju, našao je pustoš koju nije mogao podnijeti pa se vratio na svoje imanje u Križovljanu kraj Varaždina, gdje je i umro 1749. godine. Sahranjen je u mjesnoj crkvi, ali mu se ne zna grob. 
Ključne riječi: Bakić, misionar, Bosanska biskupija, franjevci, Komorno nadzorništvo, vlastelinstvo, melioracija gospodarstva, vinogradarstvo, zakonodavac, sekvestar.

\section{Uvod}

Jugoslavenska (Hrvatska) akademija znanosti i umjetnosti (JAZU) objavila je prije stotinjak godina niz dokumenata o Petru Bakiću, biskupu bosanskom ili đakovačkom. O njemu su pisali i pojedini povjesničari koji su osvijetlili neka područja njegova života i djelovanja kao što su Josip Stanić, prvi povjesničar Đakovačke biskupije, ${ }^{1}$ Matija Pavić, povjesničar i generalni vikar, ${ }^{2} \mathrm{dr}$. sc. Stjepan Sršan, ravnatelj Državnoga arhiva u Osijeku, ${ }^{3}$ dr. sc. P. Emanuel Hoško, povjesničar Hrvatske franjevačke provincije sv. Ćirila i Metoda ${ }^{4}$ te dr. sc. Dubravka Božić Bogović. ${ }^{5}$ Ti su radovi veoma vrijedni, a neprocjenjive su vrijednosti dokumenti iz Arhiva Kongregacije za širenje vjere koje su objavili dvojica đakovačkih svećenika, vlč. Antun Dević, sada župnik u mirovini, i sada već pokojni vlč. Ilija Martinović. ${ }^{6}$ Međutim, još uvijek ima nerasvijetljenih pitanja o životu i djelovanju toga vrijednoga biskupa. Biskup Petar Bakić za povjesničare je vrlo zanimljiva, ali još neproučena tema. Tristota obljetnica početka organiziranoga vinogradarstva na području Đakovštine koja se poklapa s 300. obljetnicom imenovanja Petra Bakića za bosanskoga ili đakovačkoga biskupa bila je prilika da se još više osvijetli lik toga biskupa. Za njega se obično kaže da je zbog teške naravi i sukoba sa svima oko sebe udaljen iz biskupije, ali nije se do kraja rasvijetlilo koji su bili razlozi takvoga postupka toga vrijednoga biskupa. Ovaj rad neka bude mali doprinos tom rasvjetljavanju i čin zahvalnosti biskupu koji je osuđen bez suda, za koga se ne zna gdje je provodio godine internacije (sekvestra)

\footnotetext{
${ }^{1}$ J. STANIĆ, Brevis Notitia Episcopatus Bosnensis seu Diacovariensis cum Syrmiensi uniti Ex authenticis Archivi ejusdem Episcopatus Monumentis et Celleberrimorum Virorum Danielis Farlati, Georgii Pray, Josephi Koller, aliorumque Operibus digesta a Josepho Stanich, Episcopali Saecretario Consistorii Notario et Pauperum Advocata Ao 1820., 14., privez: G. PRAY, Speccimen Hierarchiae Hvngaricae, Pars I., Posoni et Cassoviae, MDCCLXXVI.

${ }^{2}$ M. PAVIĆ, Petar Bakić, Biskup bosansko-djakovački (1716. - 1749.), u: Glasnik Biskupija bosanske i sriemske (= GBBS), 24(1896.)20, 175.-177.; 183.-185.; 191.-193.; 199.-201.; 207.-209.

${ }^{3}$ S. SRŠAN, Spor đakovačkog vlastelina biskupa Bakića i vojske 1722. godine, u: Anali Zavoda za znanstveni i umjetnički rad u Osijeku, knj. 7. (1989.), 53-78.

${ }^{4}$ E. HOŠKO, Višestoljetno djelovanje franjevaca u Đakovu (1347. - 1806.), u: Diacovensia 3(1995.)1, 373.-394.

${ }^{5}$ D. BOŽIĆ BOGOVIĆ, Petar Bakić de Lach, bosanski ili đakovački biskup (1716. - 1749.), u: Glasnik Arhiva Slavonije i Baranje 11, Osijek, 2011., 51.-63.

${ }^{6}$ A. DEVIĆ (prir.), Monumenta croatica Vaticana, Posebna izdanja 5, Zagreb, 2003., 6+265.-267. (ASCPF, SOCG, vol. 603, ff. 405r- 4407); A. DEVIĆ, I. MARTINOVIĆ (prir.), Đakovačka i Srijemska biskupija. Biskupski procesi i izvještaji 17. i 18. stoljeće, Monumenta Croatica Vaticana - posebna izdanja 2., Zagreb, 1999., 94.-95.
} 
ni gdje mu je grob. Uz korpus ovoga rada priložen je po prvi put tekst Bakićeva $\mathrm{Za}$ konika, i na originalnom starinskom hrvatskom jeziku i na suvremenom hrvatskom jeziku, te dio tužbi što ih je iznio na račun »đakovačkih franjevaca « i generala u Osijeku. Ti su tekstovi integralni dio ovoga rada. Bakića ćemo bolje shvatiti ako se budemo držali pradavnoga pravila: Ipsissima verba Bakichi legenda sunt! - »Treba čitati same Bakićeve riječi! «, što je rekao ili napisao.

\section{Mala biskupija - veliki posjedi}

Od svojih početaka Bosanska biskupija posjedovala je velika imanja s jedne i druge strane Save. Posjede u Bosni darovao joj je ban Matej Ninoslav oko 1233. godine, a posjede u Slavoniji bosanskom je biskupu Ponsi 1239. godine darovao Koloman, herceg Slavonije, što je potvrdio papa Grgur IX. pismom od 7. prosinca 1239. godine. Nakon provale i povlačenja Mongola Kolomanovu darovnicu potvrdio je njegov brat, kralj Bela IV. u poznatoj povelji zvanoj Zlatna bula, izdanoj 20. srpnja 1244. godine. ${ }^{7} \mathrm{Na}$ cijelom tom području bile su tek četiri župe, što je za jednu biskupiju svakako premalo, ali posjedi su sa svojim šumama, pašnjacima, ribnjacima i vodama bili golemi. To je područje pripadalo vukovskoj župi, a u crkvenom pogledu bilo je smješteno između Pečujske i Zagrebačke biskupije.

S vremenom su bosanski biskupi posve izgubili vezu s biskupijom preko Save i mogućnost da njom upravljaju. Đakovo je brzo postalo mjesto njihova trajnoga boravka, u kojem se ni deset godina nakon spomenute povelje već spominje biskupska rezidencija, ${ }^{8}$ malo kasnije katedrala sv. Petra, ${ }^{9}$ stolni kaptol ${ }^{10}$ pa franjevački samostan te u XV. st. i teološka škola za spremanje svećenika. ${ }^{11}$ Postavši biskupskim sjedištem, Đakovo je postalo i značajno političko središte između Save i Drave u koje su povremeno navraćali neki vladari, kao ban Tvrtko (1355. $)^{12}$ te bosanski kralj Stjepan Dabiša i ugarski kralj Sigismund. ${ }^{13}$

${ }^{7}$ A. THEINER, Monumenta Slavorum Meridionalium, T. I., Romae, Typis Vaticanis, 298.; T. SMIČIKLAS (ur. i prir.), Codex Diplomaticus, T. IV, Zagreb, 236.-240.

${ }^{8}$ T. SMIČIKLAS, Codex Diplomaticus, 494.

${ }^{9}$ A. THEINER, Monumenta Slavorum Meridionalium, 445.

${ }^{10}$ Isto, 83.; A. THEINER, Monumenta Hungarica, I, 430.

${ }^{11}$ S. KATONA, Historia critica regni Hungariae, T. XVII, Typis Regiae Universitatis, Budae, 1793., 140.

${ }^{12}$ K. JIREČEK, Spomenici srpski, Spomenik SANU-a, knj. XI., Beograd, 1892., 31.-32.

${ }^{13}$ F. RAČKI, Pokret na slavenskom jugu koncem XIV. i početkom XV. stoljeća, u: Rad JAZU, knj. 3, 1888., 136. 
Turskom najezdom propala je Bosanska ili Đakovačka biskupija, a u Mohačkoj bitci 1526. godine poginuo je i bosanski biskup Đuro Paližna (Palina). U narednih 150 godina imenovani su samo naslovni biskupi bosanski, Bosnenses alias Diacovenses, koji sve to vrijeme nisu boravili u svojoj biskupiji.

Međutim, i u dekretima imenovanja bosanskih naslovnih biskupa priznata je njihova duhovna i svjetovna vlast nad područjem između Save i Drave. Tako car Ferdinand III. u dokumentu o imenovanju fra Marijana Maravića za bosanskoga ili đakovačkoga biskupa 4. rujna 1646. godine izričito određuje da mu kao bosanskom biskupu pripadaju ti krajevi $\gg$ sa svim gradovima, gradićima, utvrdama, selima... napose grad Đakovo s njegovom okolicom, i sa svim drugim što spada između rijeka Save i Drave $\ll^{14}$. U prepirkama o pravu nad tim područjima neprestano se naglašava pravo vlasništva od pamtivijeka, ${ }^{15}$ o čemu svjedoče i starci franjevci samostana Olovo. ${ }^{16}$

Tijekom toga razdoblja župe u Đakovštini, i samo Đakovo, svojatali su i zagrebački i beogradski, odnosno smederevski biskupi. Tako npr. zagrebački biskup Martin Borković u jednoj poslanici iz 1677. godine tvrdi da je mjesto Đakovo, nekad Jako, prije pripadalo Zagrebačkoj biskupiji, a da se Đakovo po kojem su bosanski biskupi dobili svoj naslov đakovački nalazi negdje u Bosni. ${ }^{17}$ I vikari zagrebačkoga biskupa za turske dijelove Slavonije fra Petar Nikolić ${ }^{18}$ i fra Luka Imbrišimović, ${ }^{19}$ junak u oslobađanju Slavonije od Turaka, žestoko su se borili za te krajeve u prilog svome biskupu napadajući fra Nikolu Ogramića Olovčića koji je tada već bio imenovan bosanskim biskupom. ${ }^{20} \mathrm{I}$ isti fra Nikola, dok je još bio profesor u Ljubljani, upozoravao je zagrebačkoga biskupa da brani svoja prava na područja u Slavoniji protiv beogradskoga biskupa. ${ }^{21}$

\footnotetext{
${ }^{14}$ Hrvatska (dalje: HR) Nadbiskupijski arhiv Đakovo (dalje: HR-NAĐ) fond Bakić, kut. Bakić Summarium Jurium Episcopalium Diakoviensium, br. 2.

${ }^{15}$ HR-NAĐ, fond Bakić, kut. BAKIĆ, Summarium Jurium Episcopalium Diakoviensium, br. 6.

${ }^{16}$ Isto.

${ }^{17}$ R. LOPAŠIĆ, Slavonski spomenici za XVII. Viek, u: Starine JAZU, knj. 30, 40., 43.-44.

${ }^{18}$ E. FERMENDŽIN, Acta Bosnae, izd. Academia Scientiarum et Artium Slavorum Meridionalium, Zagabriae, 1892., 495.

${ }^{19}$ R. LOPAŠIĆ, Slavonski spomenici za XVII. Viek, 76.

${ }^{20}$ Isto, 115. Za biskupa Ogramića autor kaže: »Episcopi Bosnensis natura non humana, sed revera infernalis est.«

${ }^{21}$ E. FERMENDŽIN, Acta Bosnae, 512.; J. JELENIĆ, Spomenici kulturnog rada bosanskih franjevaca (1437. - 1979.), u: Starine, knjiga XXXVI, 132.
} 


\section{Jadi od Turaka oslobođene Slavonije}

U listopadu 1687. godine ušao je u Đakovo zapovjednik d'Aspremont, a deset godina poslije, tj. 27. rujna 1697. godine, darovnicom izdanom u Ebersdorfu (kod Beča) ponovio je car i kralj Leopold I. spomenutu povelju Ferdinanda III. tadašnjem biskupu fra Nikoli Ogramiću (starinom Bošnjaku iz Olova) kojom je također priznao pravo na đakovačko vlastelinstvo. $\mathrm{Na}$ temelju te povelje ušao je biskup Ogramić u Đakovo i zauzeo ga zajedno s pustom okolicom od 54 naseljena sela i 87 pustoselina. Đakovština je naime u 16. i 17. stoljeću bila sijelo turskih gospodara te sada, po njihovu odlasku, umalo najpustiji kraj u Slavoniji. Tako je primjerice krajem 17. stoljeća nabrojeno do 17000 jutara puste oranice. Što je ušlo u sastav novonastaloga vlastelinstva, saznajemo iz popisa koji je načinio provizor Emerik Szadecsky (1702.), a osječka komorska inspekcija ustupila trećem Ogramićevu nasljedniku, biskupu Petru Bakiću, a on ga je preveo na hrvatski. ${ }^{22}$

Ogramić je, uzevši u posjed vlastelinstva, prvi počeo oko Đakova obrađivati oranice, livade, vinograde itd., koliko se to tada moglo. Sve te posjede priznao je i car i kralj Karlo VI. biskupu Petru Bakiću rješenjem od 14. siječnja 1717. godine, poimence $\gg$ rezidenciju u gradu đakovačkom, samo mjesto Đakovo, a isto tako sva sela, dobra i imanja koja su tu spadala ... sa svim pravima i prihodima koje su dotadašnji biskupi mirno uživali $\ll^{23}$

Za cijelo to slavonsko područje uspostavljena je vojna uprava, tj. komorno ili kameralno nadzorništvo sa sjedištem u Osijeku, ali dolazak kršćanske vojske u Slavoniju nije stanovnicima donio željenu slobodu i mir. Naprotiv, prve su godine bile razdoblje velikih nepravdi i otimačina koje su činili njemački vojnici osloboditelji, njihovi generali, odreda stranci, od kojih su neki u oslobođenim krajevima za nagradu dobili imanja, a neki su u ime bečkoga dvora upravljali cijelom Slavonijom koja je proglašena vlasništvom carskoga dvora. Nisu prošle ni dvije godine od oslobođenja, a predstavnici Đakova (i Našica) pošli su u Našice da, po naredbi bečkoga dvora, iznesu svoje tužbe. Đakovčani se tuže, među ostalim, da malobrojno izgladnjelo stanovništvo mora hraniti četrdeset vojnika koji nisu zadovoljni onim što im se daje, nego otimaju ljudima goveda, krave, koze, kradu i uništavaju polja i vrtove, s krovova zgrada skidaju olovo, nadziru trgovinu i nabijaju cijene. Neke koji su pokušali braniti svoju imovinu zlostavljali su i ubili. Nasilje je takvo, govore predstavnici, da je od 6000 stanovnika toga kraja, koliko ih je bilo nakon odlaska Turaka, sada ostalo svega $300 .^{24}$

\footnotetext{
${ }^{22}$ HR-NAĐ, trezor, P. BAKICH, Pro usu Cnscriptionis Bonorum Deakovar (autograf).

${ }^{23}$ HR-NAĐ, fond Bakić, kut. Bakić, Korespondencija Bakić, spis od 14. siječnja 1717.

${ }^{24}$ M. SRAKIĆ (prir. i prev.), Tužba stanovnika Đakovštine protiv vojnikâ osloboditeljâ, u: Croatica christiana periodica 12(1988.)22, 197.-199. (Nakon umorstva biskupa Ogramića iz Dijecezanskog arhiva odneseni su svi dokumenti i darovnice. Među rijetkim spisima sačuvan je samo zapisnik s
} 


\section{Bakićevi prethodnici}

Biskup fra Nikola Ogramić Olovčić dao se na obnovu Đakova: izgradio je neku jadnu rezidenciju od blata i pruća. Ne znamo je li još štogod izgradio za vrijeme svoga desetogodišnjega boravka u Đakovu, ali postoje svjedočanstva da se mnogima zamjerio zbog utjerivanja crkvenoga poreza, desetine i sabiranja novca za gradnju katedrale. To ga je stajalo i glave. Naime, kad se pročulo da je, navodno, skupio mnogo novaca, provalili su razbojnici u njegov stan noću između 14. i 15. kolovoza 1701. godine te ga ubili i (kažu) orobili. ${ }^{25}$ Biskupa Nikolu naslijedio je Petar Stanislav Crnković, zagrebački kanonik i rektor najprije Bečkoga, a potom Bolonjskoga kolegija, ali je on umro prije nego što je dospio do Đakova. O njemu je njegov nasljednik Đuro Patačić de Zajezda napisao da je bio muž učen, pobožan, drag i obdaren svim krjepostima. ${ }^{26}$

Drugi Ogramićev nasljednik bio je Đuro Patačić de Zajezda (1703. - 1716.), zagrebački svećenik, kanonik i rektor Hrvatskoga zavoda u Bolonji, koji je tada imao tek 33 godine. On je u unutrašnjem prostoru tvrđave izgradio drvenu rezidenciju, a na prednjem dijelu (svetištu) predturske stolne crkve podigao novu, s drvenim tornjem. Iz Carigrada je nabavio 18 arapskih kobila i 8 pastuha i tako započeo obnovu vlastelinstva. ${ }^{27}$ Prinosi biskupskih imanja bili su slabi. Istina, oko Đakova bilo je 1702 . godine 150 jutara oranice te 100 kosaca livada i 54 motike vinograda, zatim 17000 jutara neobrađene zemlje, no da ima od čega živjeti, Patačić je od cara Leopolda I. primio i prepozituru sv. Petra kod Požege (Kaptol) od koje također nije imao nikakve koristi, a kad se nje odrekao, dobio je od cara Josipa I. prepozituru u Salavaru (Ugarska) koje se također pred kraj života odrekao. ${ }^{28}$

U vrijeme biskupa Đure Patačića u Bosanskoj biskupiji župe su vodili iz svoga samostana franjevci, članovi Provincije Bosne Srebrene. Đakovački samostan bio je jedan od prvih i najuglednijih franjevačkih samostana osnovanih izvan teritorija Bosne. ${ }^{29}$ Osnovao ga je Peregrin Saksonac, franjevac i prvi vikar Bosanske vikarije

tužbama što su ih stanovnici Đakovštine i Našica izrekli na račun vojnika pred župnicima i biskupom u Našicama 18. rujna 1689. godine.).

${ }^{25}$ A. THEINER, Monumenta Slavorum Meridionalium, Tom. II, 238.; S. BÄUERLEIN, Fra Nikola Ogramić - Olovčić biskup đakovački, posebni otisak iz revije $\gg$ Croatia sacra «, broj 22, god. XIII-XIV, 29.-33.

${ }^{26}$ HR-NAĐ, fond Patačić, tresor, PATACHICH, Diarium ep. Georgii Patachich de Zajezda, p. 1.

${ }^{27}$ HR-NAĐ, fond Bakić, P. BAKICH, De vita populi... - M. PAVIĆ, Gjuro Patačić biskup bosanskođakovački (1703-16), u: GBBS 24(1896.)7, 73., 80.-81.

${ }^{28}$ M. PAVIĆ, Gjuro Patačić biskup bosansko-đakovački, 80.-81.

${ }^{29}$ J. BÖSENDORFER, Crtice iz slavonske povijesti, Tiskom Knjigo- i kamenotiskare Julija Pfeiffera, Osijek, 1910., 293; E. HOŠKO, Višestoljetno djelovanje franjevaca u Đakovu, 375. 
(1347.), ${ }^{30}$ a kasnije i bosanski biskup (1349. - 1356.). ${ }^{31}$ Za vrijeme turske vladavine franjevci su se u đakovačkom samostanu zadržali do 1551. godine, dok ga nisu kalvini razorili. Oni su zajedno sa svojim narodom podnosili turska nasilja, a jedno od njih dogodilo se 1607. godine kad su Turci zbog neke navodne bune nabili na kolac tri franjevca i pedeset Đakovčana. ${ }^{32}$ Bosanska biskupija s ove strane rijeke Save obuhvaćala je sljedeće župe: Đakovo, Gorjane, Vrbicu i Vrpolje. Na području biskupije bilo je sedam starih crkvica, većinom drvenih, a neke od njih izgradio je biskup Đuro Patačić. U mjestima gdje nije bilo crkve misa se služila u privatnim kućama.

Biskupu Patačiću ispočetka je služila kao katedrala franjevačka crkva, nekadašnja džamija, koju je on svojim sredstvima obnovio, blagoslovio i u njoj podigao dva oltara. Dva dana prije biskupske sinode, tj. 16. svibnja 1706. godine, biskup je posvetio glavni oltar na čast Bezgrješnom začeću Blažene Djevice Marije, a drugi na čast sv. Barbare. Prvi đakovački župnik nakon oslobođenja Slavonije od Turaka bio je Ivan Grličić, dijecezanski svećenik, kojega je na tu službu postavio biskup Nikola Ogramić. Grličić je 1707. godine u Veneciji dao tiskati svoj molitvenik i katekizam pod naslovom Put nebeski. To je prva hrvatska knjiga koja je napisana u Slavoniji. ${ }^{33}$ Ta nam knjižica pruža niz podataka o svakodnevnom životu stanovnika onoga vremena hvaleći ili kudeći postupke svojih suvremenika. ${ }^{34}$ Patačić je prigodom Grličićeve smrti zapisao: »26. lipnja umro je prvi đakovački župnik Ivan Grličić, loretski pitomac, muž znanjem i životom prokušan, veoma revan pastir svoga stada, koji je htio biti sahranjen kod svojih ovaca u zajedničkom groblju. $\ll^{35}$ Iako su tada i car i biskup imali namjeru đakovačku župu povjeriti dijecezanskom svećeniku, to je zbog nedostatka dijecezanskih svećenika bilo neostvarivo. Patačić je, kao što sam piše, nakon dugoga razmišljanja odlučio pozvati franjevce da dođu u Đakovo, dati im vlast, izgraditi im samostan i sa samostanom spojiti župu. Franjevci su naime od 1687. godine kao privremeni upravitelji vodili župu Đakovo 2 u Đakovačkim Selcima gdje su se sklonili od Turaka i brinuli se o malobrojnim katolicima u Đakovu. Biskup je 1710. godine te dvije đakovačke župe ujedinio i za stalno povjerio franjevcima. On im je izgradio samostan (1711. - 1714.) i darovao znatnu parcelu

\footnotetext{
${ }^{30}$ E. HOŠKO, Višestoljetno djelovanje franjevaca u Đakovu, 373.

${ }^{31}$ M. PERVAN, Fra Peregrin Saksonac, u: Dobri Pastir 5(1955.)4, 150.-158.

${ }^{32}$ J. BÖSENDORFER, Crtice iz slavonske povijesti, 326.

${ }^{33}$ I. GRLIČIĆ, Puut nebeski ukazan csoviku od Boga po svetoj Czarqui tojest Navk karstjanski /u' kratku obilato i razborito istomacsen u jezik bossanski po D. Ivanu Garlicsichiu, xupniku djakovacskomu... Venetiis, Apud Hieronymum Albriccium, M. DCCVII. /1707/. 8 $(17 \mathrm{~cm}) / 24 / 296$ str. sa slikom.

${ }^{34}$ S. DAMJANOVIĆ, Izvori i rukavci, Hrvatska sveučilišna naklada, Zagreb, 2016, 82.

${ }^{35}$ NAĐ, fond Bakić, kut. Bakić, BAKIĆ, Diarium, Anno 1709. Die 26 Junii 1709.
} 
oranice i vinograda. ${ }^{36}$ Biskup Đuro Patačić bio je cijeloga života slaboga zdravlja, umro je mlad, u 46. godini života, a naslijedio ga je Petar Bakić.

\section{Petar Bakić - podrijetlo, misionar i izabrani biskup srijemski}

Petar Bakić rođen je u Splitu 28. rujna 1670. godine od oca Gabrijela i majke Barbare. Krstio ga je don Petar Matošić, a kumovali su mu g. Nikola Tišisić (Nicolò Tissisich) i njegova supruga Margarita. Otac mu je bio ugledni splitski građanin iz plemenita roda de Lach. Petar je imao još tri brata: Ivana, Pavla i Mateja. Ivan i Pavao naslijedili su oca, Matej je rano umro, a najmlađi Petar izabrao je svećenički poziv.

Matija Pavić, povjesničar, navodi da je Bakić studirao u Rimu, ${ }^{37}$ a Josip Stanić, naš prvi povjesničar, da je završio školovanje u Beču. ${ }^{38}$ Isto tako, Emerik Gašić izričito tvrdi da je studirao kod isusovaca u Beču, ${ }^{39}$ međutim Ivan Petar de Marchia, Splićanin, jedan od svjedoka pozvanih svjedočiti prije Bakićeva imenovanja za bosanskoga biskupa, kaže da je iz biskupovih usta čuo da je on svoje studije završio u Hrvatskoj. ${ }^{40}$ I sam Bakić u svome pismu Kongregaciji za širenje vjere piše da je u »Zagreb poslan da bi o vlastitom trošku u isusovačkom kolegiju naučio potrebno znanje o svome pozivu $\ll{ }^{41}$. Prema tomu, ako se samom biskupu i prisegnutom svjedoku može vjerovati, onda se konačno može prihvatiti i zaključiti da Bakić nije završio školu ni u Rimu ni u Beču, nego u Hrvatskoj. Taj zaključak možemo prihvatiti i na temelju činjenice da je krčki biskup Baltasar Nosandini izdao svjedodžbu da je na temelju otpusnoga pisma splitskoga nadbiskupa zaredio za svećenika Petra Bakića, splitskoga kandidata, u svojoj katedrali ne 7. prosinca, nego 17. prosinca 1695. godine. ${ }^{42}$

Petar se od prvih godina svoga svećeništva posvetio misionarskom pozivu u sjevernim hrvatskim krajevima i u južnoj Ugarskoj, a obilazeći vjernike katolike pod turskim jarmom, dospio je sve do Carigrada. To je bilo vrijeme prave seobe naroda, naime kad su te krajeve napuštali stanovnici muslimani, a dolazili kršćani, katolici i

${ }^{36}$ NAĐ, fond Bakić, kut. Bakić, BAKIĆ, Diarium, Anno1710 - 20. Xbris 1710.

${ }^{37}$ M. PAVIĆ, Petar Bakić, Biskup bosansko-djakovački (1716. - 1749.), 175.

${ }^{38}$ HR-NAĐ, trezor, J. STANIĆ, Brevis Notitia Episcopatus Bosnensis seu Diacovariensis cum Syrmiensi, nepagirano.

${ }^{39}$ E. GAŠIĆ, Brevis conspectus historicus, Essekini, Sumptibus auctoris, 1944., 37.

${ }^{40}$ A. DEVIĆ, I. MARTINOVIĆ (prir.), Đakovačka i Srijemska biskupija. Biskupski procesi i izvještaji 17. i 18. stoljeće, 94-95.

${ }^{41}$ A. DEVIĆ (prir.), Monumenta croatica Vaticana, Posebna izdanja 5, Zagreb, 2003, 6+265-267. (ASCPF, SOCG, vol. 603, ff. 405r- 4407).

${ }^{42}$ A. DEVIĆ, I. MARTINOVIĆ (prir.), Đakovačka i Srijemska biskupija, 100. 
pravoslavni. Car/kralj Leopold I. (1658. - 1705.) povjerio je Leopoldu Koloniću, ostrogonskom nadbiskupu i primasu, velikom kancelaru, kardinalu naslovniku Sv. Jeronima u Rimu, da uredi crkveni život na tek oslobođenim područjima Ugarske i Slavonije. Budući da u tim krajevima nije imao dovoljan broj svećenika, nadbiskup Kolonić pozvao je svećenike iz Dalmacije da dođu kao misionari i preuzmu pastirsku skrb za preživjele vjernike katolike i za pridošlice. Tim misionarima pridružio se i mladi revni svećenik Petar Bakić koji je kardinala upoznao u Rimu. U to vrijeme stizali su iz Srbije, tj. s Kosova, srpsko-pravoslavni prebjezi te se i u Crkvi i u državi razmišljalo o radu na njihovu sjedinjenju s Katoličkom Crkvom.

Mnogi pojedinci i skupine hvale Bakića kao revnoga misionara. ${ }^{43}$ Najstarija svjedočanstva opisuju njegovo misionarsko djelovanje na kraju 17. i početkom 18. stoljeća. Fra Nikola Okrugić Olovčić, bosanski biskup, posvjedočio je da je Petar živio i radio o vlastitu trošku i pod turskom tiranijom te da je izlagao život velikim opasnostima i da je za to vrijeme priveo iz pravoslavlja u Katoličku Crkvu više osoba. ${ }^{44}$ Jedna skupina vjernika svjedoči da je g. Petar živio s njima i izložio svoj život opasnostima. ${ }^{45}$ Osobito bogato svjedočanstvo o Bakiću dao je neki o. Josip, redovnik Presvetoga Trojstva. On je u listopadu 1699. godine krenuo u pratnji g. Wolfganga kneza Ethingena (!), velikoga carskoga legata pri Visokoj porti, iz Beča u Carigrad. Bakić mu je tom zgodom pomogao da razmijeni sto zarobljenih Turaka za zarobljene kršćane, među kojima je bio i jedan Bakićev rođak. I Bakić je poslije krenuo prema Carigradu, na tom putu i sam je obolio od kuge, ali je i u bolesti pomagao drugim bolesnicima dijeleći sakramente euharistije i ispovijedi, a u Ugarskoj je vratio u krilo Katoličke Crkve osamdeset i sedam krivovjeraca. ${ }^{46}$ Po mandatu samoga cara držao je kateheze te misionario oko Požege, Beograda te po Slavoniji i tada obratio stotine luterana, židova, šizmatika. I kardinal Leopold Kolonić, nadbiskup ostrogonski, nekoliko je puta posvjedočio da je Bakić bio punih osam godina dvorski tumač ilirskoga (hrvatskoga) jezika bez stana, hrane i plaće. Osim toga, djelujući među šizmaticima, mnoge je od njih vratio Crkvi. ${ }^{47}$ I Kolonićev nasljednik, kardinal Kristian August, ostrogonski nadbiskup, potvrdio je ono što je o Bakiću rekao njegov prethodnik i dodao neke pojedinosti, npr. da su se njegovom revnošću tri

\footnotetext{
${ }^{43}$ HR-NAĐ, fond Bakić, kut. Bakić, Testes set Testimonia Multorum, et magnorum abunde Meritorum Illustrissimi et Reverendissimi Dni Petri Bakich de Lach Episcopi Bosnensis alias Diakovensis. Frater Nicolaus Plumbensis a Posega Sacrmae Cesareae Regiaeque Mattis Consiliarius et Divinae, ac Sanctae Sedis Apostolicae Dignatione Diaccoviensis, seu Bosnensis Episcopus 1700. do 1727.

${ }^{44}$ HR-NAĐ, fond Bakić, Testes set Testimonia, 3.-4.

${ }^{45}$ HR-NAĐ, fond Bakić, kut. Bakić, Testes et Testimonia, 4.-5.

${ }^{46}$ Isto, 6.-8.

${ }^{47}$ Isto, 15.-16.; 21.-23.
} 
pravoslavna episkopa vratila u krilo Katoličke Crkve, među njima pakrački biskup Petar Ljubibratić i vlaški arhiepiskop Efrem Banjanin. ${ }^{48}$

Tu revnost uočili su i carevi i kraljevi Leopold I., Josip I. i Karlo VI., na dvoru kojih je Bakić bio tumač ilirskoga (hrvatskoga) jezika. Car Leopold I. imenovao ga je opatom Blažene Djevice Marije od Babolcza (Bobovca preko Drave u Mađarskoj), a za vrijeme Rakoczyjeve bune oko 1700. godine bune pozivao je Bakić na mir i vjernost zakonitom vladaru. $S$ pravoslavnima je raspravljao ne samo pismeno nego je vodio i dispute s njima. Za vrijeme jednoga disputa napao ga je sugovornik, pravoslavni pop koji je, vidjevši da će ga Bakić pobijediti, skočio i nastojao fizički dokazati ispravnost svojih stavova do te mjere da je Bakić jedva ostao živ. Istinitost toga događaja potvrdila je skupina svjedoka, među njima prvi svjedok Josip Leopold, prisegnuti pravnik, i Godfried Taun, kirurg koji ga je primio u bolnicu. ${ }^{49}$ Bakića je veoma cijenio i bečki nuncij Giulio Piazza, koji ga je nakon smrti srijemskoga biskupa Josipa Favinija predložio za srijemskoga biskupa (1710.), što je car i kralj Josip I. prihvatio i imenovao ga naslovnim biskupom srijemskim, ali Rim to nikada nije potvrdio, najvjerojatnije jer se tomu žestoko protivio Luka Natalis, smederevski, odnosno beogradski biskup, zapravo, župnik župe Nijemci, rodom iz Dubrovnika. ${ }^{50}$ Tako je Bakić do imenovanja za bosanskoga biskupa ostao naslovni, odnosno izabrani srijemski biskup, ${ }^{51}$ ali su ga za to vrijeme predlagali i za neke druge službe, npr. za nasljednika senjskoga biskupa, koadjutora senjskoga biskupa itd. ${ }^{52}$

\section{Petar Bakić - bosanski, odnosno đakovački biskup}

Petar Bakić svojim se životom i radom nametnuo kao kandidat za bosanskoga biskupa. Nisu prošla ni dva mjeseca od smrti biskupa Đure Patačića de Zajezda (1. ožujka 1716.), a već ga je kralj Karlo VI. imenovao, a papa Klement XII. (1730. - 1740.) dana 12. prosinca iste godine potvrdio za bosanskoga, odnosno đakovačkoga biskupa, dakle male biskupije koja je posjedovala velika imanja.

Bakić se odmah nakon imenovanja za biskupa dao na uređenje svoje biskupije u kojoj je mnogo toga bilo srušeno, demolirano, zapušteno, i to s onom istom energijom

\footnotetext{
${ }^{48}$ Isto, 24.-28.

${ }^{49}$ Isto, 29.-30.

${ }^{50}$ D. BOŽIĆ BOGOVIĆ, Petar Bakić de Lach, bosanski ili đakovački biskup (1716. - 1749.), 53.-54. Autorica toga članka vrlo dobro koristi se dokumentima o biskupu Bakiću sačuvane u Arhivi Kongregacije za širenje vjere, objavljene u vrlo vrijednom i stručnom izdanju: A. DEVIĆ (prir.), Đakovačka i Srijemska biskupija. Spisi generalnih sjednica Kongregacije za širenje vjere 18. stoljeće, Zagreb, 2003., passim.

${ }^{51}$ A. THEINER, Monumenta Slavorum meridionalium, T. II., 24.

${ }^{52}$ J. STANIĆ, Brevis Notitia, 16.
} 
kojom je misionario na tim širokim prostorima. Iz dokumenata o njegovu životu i djelovanju može se zaključiti da je doista mnogo učinio za biskupiju i vlastelinstvo. ${ }^{53}$

Prva je biskupova briga bila stolna crkva unutar zidina biskupskoga dvorca koju su Turci srušili do temelja, a Patačić je na njezinim jedva vidljivim temeljima podigao samo svetište, dok ju je Bakić produžio od svetišta do glavnih vrata te izgradio kor na koji je smjestio orgulje (organum) s četiri trube, jedan novi timpan, bas, fides ${ }^{54} \mathrm{i}$ druge glazbene instrumente. Uz crkvu je podigao drveni toranj. Isto tako, izgradio je prostranu kriptu po sredini zidom razdijeljenu na dva dijela, jedan za ukop biskupâ, a drugi za ukop svećenikâ. Crkvu je dao oslikati i za nju nabaviti svijećnjake, lampe, relikvijare, svećeničku odjeću, kazule, dalmatike i ostalo ruho potrebno za bogoslužje, a sve se to smjestio u dva velika ormara.

Biskup je uz to nabavio 29 zvona, dijelom za svoju katedralu, a dijelom za filijale. Nabavio je 27 kaleža, potom 7 ostenzorija, ${ }^{55}$ ciborij i 3 pastorala, ${ }^{56}$ uz onaj što ga je zatekao nakon smrti svoga pobožno preminuloga prethodnika Nikole Olovčića. Izgradio je sakristiju, a iznad nje oratorij, odnosno kućnu kapelicu, presvođenu i iznova izgrađenu.

Bakićev prethodnik biskup Patačić pokrio je staru tursku mošeju i pretvorio je u crkvu sv. Jurja, ali je ona bila sa svih strana otvorena pa su u nju ulazili svi, i putnici i životinje, tako da je više služila za dnevno i noćno sklonište nego za službu Božju. Neki su na njoj probijali zidove i tražili tursko zlato. Bakić je tu mošeju podzidao, namjestio oltar Svih svetih i osposobio je da se u njoj mogla služiti misa nedjeljom i blagdanima. ${ }^{57} \mathrm{Na}$ nju je postavio dva zvona da zvone Gospino pozdravljenje ujutro, u podne i navečer, a izgradio je i drveni kor za orgulje i glazbala. Biskup je obnovio i crkvu sv. Bartola u Mikanovcima, kao i crkvu sv. Martina u Selcima i Blažene Djevice Marije u Dragotinu. U dragotinskoj šumi, uz novu kraljevsku cestu na putu prema Brodu, postoji zidana, ali trošna crkva sv. Marka. Za njezin je popravak već bio spreman materijal, a o njoj i o zvonima na njoj brinuo se jedan eremit (pustinjak), član reda sv. Augustina. ${ }^{58}$

\footnotetext{
${ }^{53}$ Svjedočanstvo je iz pera Petra Slavića koji je dva mjeseca boravio kod biskupa Bakića i razgovarao s njim i od njega čuo što je sve učinio biskup; osim toga, u biskupiji se pripovijedalo o biskupu i biskupiji.

${ }^{54}$ Glazbalo slično violini.

${ }^{55}$ Pokaznica ili monstranca.

${ }^{56}$ Biskupski štapovi koji i danas nakon restauracije svjedoče o raskoši toga vremena.

${ }^{57}$ To je danas župna crkva Svih svetih koju je kasnije, za vrijeme gradnje katedrale, biskup Strossmayer obnovio u istočnom stilu. Ponovno je uređivana 1990. godine. Danas služi za župne potrebe.

${ }^{58}$ Pustinjak. Poslije oslobođenja Slavonije od Turaka otkrilo se da po šumama još uvijek ima pustinjaka, samotnjaka.
} 


\section{Petar Bakić - vlastelin}

Iako su đakovački biskupi i prije Bakića obrađivali zapuštene zemlje i vinograde, on je prvi započeo organizirano meliorirati gospodarstvo na biskupskom vlastelinstvu. Rijeke i rječice koje su protjecale kroz vlastelinstvo Bakić je iskoristio za izgradnju vodenica. Najznačajnija među njima bila je vodenica zvana Ribnik, ali je bilo i drugih na Biđu i Jošavi, a gradio je i popravljao i druge drvene mlinove na životinjski pogon (krave, volovi, konji). Time je išao na ruku i svojim podanicima koji su dotad morali ići na Savu mljeti žito. Na posjedu je podigao vrt i majur za 250 velikih konja, uredio ribnjak u kojem je uvijek bilo vode i za najveće zime, izgradio staklenik (Glashaus) za egzotične i osjetljive biljke. Gornji kat jedne kule preuredio je za žitnicu, a donji pretvorio u hladnjak s ledom, u kojem se i za velike žege mogla čuvati hrana. ${ }^{59}$ Bakić je 1719. godine nabavio još 30 arapskih kobila i isto toliko pastuha. Za njih je dao 30 jutara dvadesetogodišnje hrastove šume. Prema zapisu prefekta vlastelinstva Andrije Keczkemetyja Bakić je već 1728. godine u stadu imao 86 arapskih kobila i 5 pastuha te 288 komada pomlatka, a izvan stada 270 jahaćih konja. ${ }^{60}$ Biskup je uredio prostorije svoga dvora za potrebe ekonomije, napose kule koje su stajale na četirima uglovima biskupskoga dvorca.

Nema točnih podataka o tome koliko je Bakić imao oranica, ali nove prostrane žitnice svjedoče da je i njih znatno povećao. Na cijelom području svojih posjeda izgradio je putove, napose onaj kraljevski put od Osijeka do Broda na kojem je radi sigurnosti putnika i robe od hajduka dao posjeći u širini od 50 koraka stara debela stabla. Podigao je i 18 novih mostova i to rekordno brzo, tj. od 3. studenoga 1726. do 3. ožujka 1727. godine. Sve te radove osobno je nadgledao on sam; živio je s radnicima na cičoj zimi, a nedjeljama i blagdanima služio im svetu misu, osobno ih pratio i na poslu hrabrio. Sve je to osobno opisao i pečatom potvrdio Petar Slavicz koji je neko vrijeme proveo s biskupom. Njegovo svjedočanstvo potpisala su i šestorica župnika iz susjednih župa te jedan carsko-kraljevski notar iz Požege. ${ }^{61}$ Iako su ti putovi bili na dobro i samih podanika, oni su se i zbog toga pobunili. Uz to veoma iskreno i bogato svjedočanstvo postoje i brojna druga svjedočanstva iz vremena njegove misionarske djelatnosti i iz vremena njegove biskupske službe

\footnotetext{
${ }^{59}$ HR-NAĐ, fond Bakić, kut. Bakić, Testes et Testimonia, 31-43. (Svjedočanstvo Petra Slavića /Slavich/ od 28. veljače 1728.).

${ }^{60} \mathrm{HR}-\mathrm{NAÐ}$, fond Bakić, kut. Bakić, A. KECZKEMETY, Relatio de cultura armentorum et pecorum in Dominio Episcopali Anno 1737.

${ }^{61}$ HR-NAĐ, fond Bakić, kut. Bakić, Testes et Testimonia, nav. mj. 31-43.; M. PAVIĆ, Petar Bakić biskup bosansko-đakovački (1716. - 1749.), 184-185.
} 
u kojima potpisnici dirljivim riječima opisuju humanitarno-karitativnu djelatnost biskupa prema bolesnima i siromašnima, siročadi i bijednima. ${ }^{62}$

\section{Vinogradarstvo}

Posebna briga biskupa Bakića kao vlastelina bili su vinogradi $i$ vinogradarstvo, što nije ništa neobično jer je to tradicija možda od vremena Rimljana, koju su nastavili i Turci. Prema podatcima Turci su na đakovačkom području imali zasađenih 200 jutara vinograda koji su davali dobro (lijepo) vino, ali koji su nakon njihova odlaska bili zapušteni. Istina, prema vjerskim zakonima Turci nisu smjeli piti alkohol, međutim prema veličini vinograda i količini vina čini se da su ga oni ipak trošili i to obilno. Biskup je u svojim zapisima nešto zabilježio o obrađivanju vinograda za vrijeme Turaka. ${ }^{63}$ (Prilog 1.)

Nakon odlaska Turaka jedan dio vinograda u Štrbincima obrađivao je biskup Đuro Patačić, a drugi dio Vojna komora. Bakić je vinograde sadio u Trnavi i oko Đakova, a za nekoliko godina povećao ih je sa 100 na 400 motika (kopača). ${ }^{64}$ Prema Zakoniku koji je izdao za stanovnike svojih dobara ona sela koja su obrađivala vinograde nisu imala drugih obveza, npr. voziti drva u Osijek (fate) ili izgrađivati nasipe za mostove (fosponte) i sl. Njihov jedini posao bili su vinogradi, a u vrijeme obrezivanja i kopanja vinograda i berbe grožđa i susjedna su sela morala priteći u pomoć da se ti poslovi na vrijeme završe. ${ }^{65}$ Vinogradi su davali 1400 oka dobroga vina. ${ }^{66}$ Monopol na prodaju vina i rakije imao je isključivo gospodar, tj. vlastelin biskup, a piće se $\mathrm{u}$ pravilu točilo i prodavalo isključivo u vlastelinskim gostionicama (bircuzima). Velim u pravilu jer je protiv toga pravila vojna komanda u Osijeku davala biskupovim podanicima dopuštenje da otvore gostionice do te mjere da je u Đakovu, uz jednu vlastelinsku gostionicu, bilo jedanaest privatnih.

U opisu svakoga sela naveden je i podatak kojom se djelatnošću bavilo, koliko je posjedovalo šume, oranice, livada i vinograda. Glede posjedovanja vinograda, podatci su sljedeći: Slatinik 7,5 motika; Drenje 15 motika (neobrađenih), Pridvorje 20 motika, Nabrđe 30 (neobrađenih), Preslatinci 11 motika, Gašinci 11 motika, Slobodna Vlast 10 motika, Ratkov Potok 9 motika, Silovci 10 motika, Musić 4 mo-

\footnotetext{
${ }^{62}$ HR-NAĐ, fond Bakić, kut. Testes et Testimonia (nepagirane stranice).

${ }^{63}$ HR-NAĐ, fond Bakić, trezor. Bakić, Pro usu Conscriptionis Bonorum Deakovar, 4-5.

${ }^{64} 1$ motika $=800 \mathrm{~m}^{2}$.

${ }^{65}$ HR-NAĐ, fond Bakić, Pro usu Conscriptionis Bonorum Deakovar (autograf), Anno Dni 1725. Diakovae Die vero 20 Maji., t. 2., 3., 4., 13., 18., 28.

${ }^{66} 1$ oka $=1,41471$.
} 
tike, Dubovik 9 motika, Majar 13 motika, H(a)rknovci 16 motika, Trnava 4 motike, Radinovci 3,5 motika, dakle svega 173 motike vinograda. ${ }^{67}$

Biskupu Petru Bakiću povjesničari priznaju da se odlikovao prosvjetiteljskim duhom, napose na području gospodarstva. Organizirao je trgovinu ratarsko-stočarskim proizvodima te podignuo više skladišta za hranu. »Razvijanjem vlastelinskih stručnih službi počela se u gradu osjećati potreba za obrtnicima, a započelo je i pritjecanje sezonske radne snage. Dao je obnoviti opustjele vinograde i vodenice, nastavio s obnovom ergele, a obnovio je i biskupski dvor. Umnogome je doprinio novoj graditeljskoj vizuri Đakova i Đakovštine odjenuvši ih u barokno ruho. $\ll^{68}$

\section{Bakićevo Upisagnije - Uredba/Zakonik}

Kao duhovni i zemaljski vladar, tj. kao biskup i vlastelin, Bakić je imao pravo izdavati zakone koji su vrijedili za stanovnike njegova vlastelinstva, odnosno vjernike njegove biskupije. $U$ tom smislu on je izdao pravni dokument pod naslovom Upisagnije, tj. Uredba, odnosno Zakonik, koji je vrlo važan za poznavanje biskupove osobe, njegova karaktera, naravi i ćudi, kao i života stanovnika njegova vlastelinstva. Upisagnije imaju 69 točaka (kanona) koje obuhvaćaju sve važne vidove života podanika. Biskup je vrlo krut, ali pravedan. Naime, uza svu žestinu, štitio je djecu, starce, siromašne i udovice i nije dopuštao da ih se poziva na posao. On uređuje odnose u obitelji između djece i roditelja, u društvu odnos podložnika i gospodara, traži poštovanje seoskih knezova koji zastupaju gospodara, gostoljubivost prema pridošlicama, napose Nijemcima, koji kao sirotinja stižu u naše krajeve, traži poštenje, a kažnjava korupciju. ${ }^{69}$ Biskup propisuje i kazne koje su vrlo teške, ponižavajuće, upravo drastične, za naše vrijeme neshvatljive. Dokument je vrlo zanimljiv $\mathrm{s}$ jezičnoga i ortografskoga stajališta. Bakić piše teško razumljivim hrvatskim jezikom, ikavicom, ni dalmatinskom ni slavonskom, s mnogo stranih, napose turskih riječi. Neobična je i Bakićeva ortografija, teško je zaključiti koju je on slijedio, to nije ni ortografija južne Hrvatske ni kajkavskoga kraja, a ni Slavonije. Koliko nam je poznato, tekst Bakićevih Upisagnija objavljivan je tek fragmentarno, pretočen u suvremeni hrvatski jezik, no bilo bi dobro da ga obrade i pravnici i jezikoslovci. Originalni tekst Upisagnija i prijevod na suvremeni hrvatski jezik (Prilog 2.), zajedno sa starinskim i stranim riječima, integralni je dio ovoga rada.

${ }^{67}$ I. SRŠAN (prev. i prir.), Naselja u Istočnoj Slavoniji krajem 17. i početkom 18. stoljeća, Državni arhiv u Osijeku, Osijek, 2000., 132.-164.

${ }^{68}$ Z. NOVAK, Crkva i vjerske prilike, u: L. ČORALIĆ (ur.), U potrazi za mirom i blagostanjem. Hrvatske zemlje u 18. stoljeću, Zagreb, 2013., 172.

${ }^{69}$ HR-NAĐ, fond Bakić, kut. Bakić, Pro usu Conscriptionis, passim. 


\section{Život podanika na vlastelinstvu}

Dva dragocjena rukopisa opisuju pojedina mjesta Đakovštine ${ }^{70} \mathrm{i}$ život tamošnjih stanovnika, Uzgoj životinja na vlastelinstvu i Zakonik za ponašanje podanika. ${ }^{71}$ Taj drugi spis ugradio je Petar Lukić, upravitelj biskupskih dobara u Đakovu, u svoj Izvještaj biskupu Josipu Antunu Ćolniću iz $1752 .{ }^{72}$ On je sačuvan samo u hrvatskom prijevodu, a preveli su ga i objavili dr. Andrija Spiletak, kanonik i profesor, i dr. Stjepan Romić, veterinar i redoviti profesor. ${ }^{73}$

Biskup piše da narod živi vrlo siromašno, u drvenim kućama pokrivenim daskom ili slamom, s malim prozorima koji su više služili kao puškarnice nego za dovod svjetla. Kuće su najčešće imale dvije prostorije: u velikoj sobi stanovali su ukućani, uz zidove su bili poredani kreveti (veliki za domaćina, krevetići i zipke za djecu), u sredini je bio stol za kojim su objedovali muškarci, a žene i djeca jeli su na podu ili za manjim stolovima. U drugoj prostoriji bilo je ognjište za kuhanje i pečenje. Ta prostorija, bez tavana, služila je i za sušenje mesa. Među ljudima bio je razvijen osjećaj za zadružni život. To je, kaže Bakić, ostalo još od turskih, nesigurnih vremena. Zadruga je svake godine birala svoga starješinu koji ju je zastupao pred vlastima.

Hranili su se najviše grahom, krumpirom i kupusom, najčešće začinjenim mašću, a dosta se trošilo i mesa. Kolači su se zaslađivali medom. Najčešće se pravila savijača od sira, oraha i pekmeza. Odjeću su pravili sami od krzna, vune i lana. Žene su prele lan i vunu. Narod u Đakovštini ima lijepu narodnu nošnju, koju sam izrađuje. Po selima je nepismenost velika, no u svakom selu ima onih koji znaju čitati i pisati. Zemlja se ore drvenim plugovima, a kopa motikom. Dosta je rašireno voćarstvo, najviše ima šljiva (požeška šljiva) od kojih se peče valjana rakija i pekmez. U doba Turaka u Slobodnoj Vlasti bio je velik voćni rasadnik požeškoga paše iz kojega su se besplatno dijelile sadnice. ${ }^{74}$

Što se stočarstva tiče, ponos biskupa Bakića bili su konji koje su i on i njegov prethodnik nabavili iz Carigrada. On je inzistirao da stočarstvo bude na visini, ne samo na vlastelinstvu nego i kod podanika. Za stočarstvo Đakovštine, tj. za čuvanje krava,

\footnotetext{
${ }^{70}$ HR-NAĐ, trezor, P. BAKIĆ, Pro usu Conscriptionis Bonorum Deakovar.

${ }^{71}$ HR-NAĐ De vita populi et de cultura armentorum et pecorum Diacovae et eius Districtus Anno Domini 1719.

${ }^{72}$ HR-NAĐ fond Bakić, P. LUKIĆ, Relatio de statu culturae armentorum et pecorum Dominii Dioecesis Diacovensis et eius districtus anno 1752.

${ }^{73}$ HR-NAĐ, fond Bakić, kut. Bakić, P. LUKIĆ, Izvještaj o stanju stočarstva spahiluka Biskupije đakovačke i srijemske i njihove okolice od 1752. godine (autograf).

${ }^{74}$ HR-NAĐ, P. BAKICH, De vita populi.
} 
konja i goveda te ovaca, vrlo je važan ovčarski pas. Bakić je opisao tog psa i taj je opis uzet kao pedigre hrvatskoga ovčara. ${ }^{75}$

\section{Biskup Petar Bakić i đakovački franjevci}

Težu stranu života i djelovanja biskupa Petra Bakića predstavljao je njegov odnos prema drugima: franjevcima, vojnim vlastima i podanicima. Sljedeći dio ovoga rada posvećujem tom pitanju. Da se dobije prava slika toga vida njegova života i djelovanja, trebalo bi proučiti dokumente ne samo domaćih arhiva, biskupijskih i franjevačkih, nego i arhive Ratnoga savjeta u Beču te važnijih arhiva u Rimu, i Kongregacije za širenje vjere i Tajnoga vatikanskoga arhiva. Nije dovoljno reći: »Bakić je bio žestok, Bakić je otimao od franjevaca njihova prava koja su stjecali trpeći s narodom «, nego treba gledati širi kontekst i proučiti koji su to događaji i koja društvena, politička i crkvena kretanja u našim krajevima, u Austrijskoj Monarhiji i Europi utjecali na život u Crkvi i društvu. U suprotnom slučaju biskup Bakić će u nas proći onako kako je prošao za života: suđen i osuđen, bez prava na obranu. On je tako prošao nakon istrage 1722. godine. Da se bar malo popuni ta praznina, uz ovaj rad objavljuju se neki izvorni Bakićevi tekstovi koji bar donekle daju odgovore na neka pitanja. Kad su Bakićevi kapelani primijetili da se vlasti ne obaziru na njegovu obranu, onda su kao očevidci iznijeli njegove prigovore na postupke i franjevaca i vojnih vlasti i podložnika, kao svjedočanstvo onoga vremena.

Imenovanjem Petra Bakića za đakovačkoga biskupa promijenili su se odnosi između biskupa i franjevaca. Budući da su sve župe i sva pastva bili povjereni franjevcima, biskupova jurisdikcija bila je vrlo ograničena, čak i upitna, zato je on htio franjevce ukloniti sa župa, pogotovo s đakovačke, i postaviti svjetovne svećenike te ustanoviti stolni kaptol s četirima kanoničkim mjestima. Ti su planovi bili neostvarivi jer biskup nije imao dovoljno svjetovnih svećenika. U toj situaciji franjevci su se, osjetivši se ugroženima, pozivali na svoja dugogodišnja pastoralna prava i stečene zasluge, ${ }^{76}$ a biskup na odredbe Tridentskoga koncila i kanonskoga prava o biskupskoj službi. Biskup je često tužio đakovačke franjevce i u Beč i u Rim, prigovarajući im je da vode sablažnjiv život, da su neuki i nemarni, da ne poštuju crkvenu vlast, da bez biskupove ovlasti podjeljuju sakramente i proglašavaju oproste. ${ }^{77}$ Optužio ih je da ne poštuju odredbe Patačićeve biskupijske sinode. No nisu ni oni njemu ostali dužni optužujući i njega i njegove kapelane; njega za dokidanje »njihovih prava«

\footnotetext{
${ }^{75}$ S. ROMIĆ, Hrvatski ovčar, u: Moj pas, Službeno glasilo kinološkog saveza SR Hrvatske, Izvanredni broj 1977., 1.-56.

${ }^{76}$ F. E. HOŠKO, Franjevci i poslanje Crkve u kontinentalnoj Hrvatskoj, Zagreb 2001., 141.-144.; E. HOŠKO, Višestoljetno djelovanje franjevaca, 386.

${ }^{77}$ M. PAVIĆ, Gjuro Patačić biskup bosansko-đakovački (1703-16), 63.-64
} 
i strogost, a kapelane za nemar u pastoralnoj službi. U parničenju s biskupom franjevci su često tražili zaštitu od vojnih vlasti u Osijeku, koje su redovito presuđivale franjevcima u korist, pogotovo kad je riječ o pitanju vlastelinstva, ali i o crkvenim (duhovnim) pitanjima. Bez uspjeha su bili biskupovi apeli na carski dvor koji nije

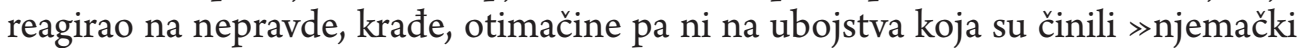
vojnici $\ll$ i vojne vlasti koje su otimačinom i upadima na biskupska dobra nadoknađivali slabe plaće. ${ }^{78}$ Ali su u Beč i Rim slali optužbe protiv biskupa i vojne vlasti u Osijeku i franjevci i biskupovi podanici. Na zakazana sudska ročišta biskup često nije dolazio, a presude su većinom donošene u prilog franjevcima. Sveta stolica pitala je susjedne biskupe jesu li optužbe protiv Bakića istinite, a oni su odgovorili da na život i djelovanje franjevaca nemaju nikakvih pritužbi. Bakiću je odbijena molba da ustanovi stolni kaptol, a u isto su vrijeme franjevci dobili dopuštenje da u đakovačkom samostanu otvore studij filozofije. ${ }^{79}$ Vrhunac napetosti i svađa između biskupa i franjevaca đakovačkoga samostana bila je sahrana biskupova sluge 19. rujna 1747. godine na kojoj je došlo do fizičkoga obračuna. ${ }^{80}$ (Prilog 5.)

\section{Vojne vlasti prema biskupu Bakiću}

Carsko-kraljevskim poveljama od srednjega vijeka sve do biskupa Bakića bosanskim biskupima priznato je vlasništvo nad onim dijelom Kolomanove darovnice koji se nalazio s ove strane Save, ali su se istovremeno zemlje oslobođene od Turaka smatrale carsko-kraljevskim vlasništvom. Zbog toga su posjedi bosanskoga ili đakovačkoga biskupa bili trn u oku i vojnim i građanskim vlastima u Osijeku i Beču. Bečki dvor oslobođeni teritorij dijelio je svojim ljudima, tuđoj vlasteli i generalima koji su se istaknuli na raznim bojištima Europe. Stari su gospodari slavonskih posjeda izumrli ili u međusobnim zadjevicama i ratovima ili u ratovima protiv Turaka. $\mathrm{U}$ te se carske posjede ubacio bosanski biskup uporno dokazujući pravo vlasništva nad svojim posjedima. Komorno nadzorništvo u Osijeku zadavalo je biskupu Petru Bakiću velike neprilike u posjedu i upravi, ali i biskup nadzorništvu zbog svoje žestoke ćudi i zahtjeva da vojne vlasti poštuju njegovo carskim ukazima zajamčeno vlasništvo. Izvor nedoumica i napetosti bila je i činjenica da tako malena biskupija, sa svega četirima župama, posjeduje tako prostrana imanja.

Povredama biskupske i vlastelinske vlasti nije bilo kraja, a u njima je prednjačila vojna vlast koja je primjerice na svoju ruku oslobađala biskupove podanike vlastelinskih obveza i onih koje su imali spram biskupa, prisvajala si pravo suditi, oslobađala one koje je biskup osudio. Biskup Bakić pokrenuo je 1722. godine istragu

\footnotetext{
${ }^{78}$ S. SRŠAN, Spor đakovačkog vlastelina biskupa Bakića i vojske 1722. godine, 54.-55.

${ }^{79}$ F. E. HOŠKO, Slavonska franjevačka učilišta, Zagreb, 2011., 290.

${ }^{80}$ HR-NAĐ, fond Bakić, kut. Bakić, Izvještaj o sahrani.
} 
protiv generala Maximiliana Petrascha i Osječke inspekcije, odnosno protiv $\gg$ njemačkih vojnika «, ali i protiv franjevaca i njihova odnosa prema njemu. U svojoj nemoći biskup se obratio Nikoli Palfiju, ugarskom palatinu, a on je imenovao svoga čovjeka i pečujski kaptol da provedu istragu. Istraga je trajala dugo, ispitani su mnogi svjedoci. Komisija je išla od mjesta do mjesta, ispitivala pojedince koji su davali svoje iskaze kao očevidci ili svjedočanstvo o onome što su od drugih čuli. Zapisnik istrage, sastavljen na latinskom jeziku, iako su svjedoci govorili hrvatski, čuva se u Županijskom arhivu $u$ Pečuhu. ${ }^{81}$ Istraga je bila javna, svatko je dao svoj iskaz pod imenom i prezimenom, zabilježeno je odakle je svjedok i odakle su mu poznati podatci. Gotovo svi upitani svjedoci, bili katolici ili pravoslavni, odgovorili su da su biskupove optužbe točne. Kad je vojna vlast vidjela kakav će zaključak donijeti istražno povjerenstvo, spriječila je njegov daljnji rad, a svjedocima zabranila da o tome ikome išta govore. Biskup je protestirao kod palatina i pečujskoga kaptola, ali uzalud. Povjerenstvo je zaključilo: »Iz ovog se vidi, da ono što su izjavili pod zakletvom brojni svjedoci, ne samo u Đakovu nego i iz mnogih okolnih biskupovih sela, nedvosmisleno govori o teškim povredama biskupovog prava kao vlastelina i biskupa. $\ll^{82}$ Takav završetak istrage ne treba čuditi jer je iste godine car Karlo VI. izdao novu povelju kojom je franjevcima potvrdio pravo vodstva župa. ${ }^{83}$ Biskupove točke optužbe protiv franjevaca u sporu 1722. godine zabilježio je biskupov kapelan Martin Paluh. ${ }^{84}$ (Prilog 3.)

\section{Podanici prema biskupu}

Obveze podanika prema vlasteli bile su velike. Naime, još je uvijek trebalo uzdržavati vojsku, Komora je ubirala sredstva za državne potrebe i za cara, a vlastelin je tražio i sredstva i težake za uređenje i obradu opustošene zemlje. To se sve svalilo na leđa jadnoga kmeta. On je za vlastelina pekao opeke, kopao kanale, gradio mostove, uređivao putove, priređivao građu, (do)vozio drva, obrađivao oranice i vinograde itd. Još od prije Turaka postojala je i ostala desetina na sve proizvode, na svaki oblik zarade i na svakoga pojedinca, koja se plaćala ili u novcu ili odrađivala raznim poslovima. Da obveze budu podjednako raspoređene, biskup je u tzv. Konskripciji (Popisu vlastelinstva) sve propisao. Jedni su biskupa čuvali oružjem kao hajduci i katane, a drugi obrađivali vinograde, vozili drva u Osijek ili žito u vodenice i

${ }^{81}$ Županijski arhiv Pečuh, Kaptolski spisi br. S+3, 1722, navedeno prema: S. SRŠAN, Spor đakovačkog vlastelina biskupa Bakića i vojske 1722. godine, 55. Autor toga članka objavio je cijeli Zapisnik u prijevodu na suvremeni hrvatski jezik.

${ }^{82}$ S. SRŠAN, Spor đakovačkog vlastelina biskupa Bakića i vojske 1722. godine, 75.

${ }^{83}$ E. HOŠKO, Višestoljetno djelovanje franjevaca, 385.

${ }^{84}$ J. STANIĆ, Brevis Notitia, 68.-70. 
mlinove. Podložnici su bili veoma nezadovoljni i novčanim nametima i ubitačnom brzinom kojom je biskup zahtijevao izgradnju kraljevskoga puta između Osijeka i Broda. U zapisniku istrage, provedene 1722. godine, nema izjava ili optužbi protiv biskupa vlastelina. Međutim, među nezadovoljnicima koji su došli tužiti biskupa 1728. godine bili su i stanovnici Đakova, Budrovaca i drugih mjesta. A kako su oni tamo dospjeli, opisali su biskupovi kapelani koji svjedoče da su Budrovčani bili nahuškani, da im se prijetilo teškim osvetama, kao što je rezanje nosa i ušiju, ako ne budu išli tužiti biskupa ${ }^{85}$ (Prilog 4.)

\section{Pokušaj tumačenja biskupovih postupaka}

Samo po sebi nameće se pitanje: Koji su razlozi tih čestih sukoba između biskupa Bakića i svih oko njega? Čini se da ih treba prije svega tražiti u njemu samome, ali i izvan njega. Prvi razlog jest biskupova teška, žestoka narav. Kao čovjek s juga reagirao je brzo i emotivno, nastupao autoritativno i žestoko, a sudeći prema njegovu Zakoniku i drastično. ${ }^{86}$ On nije shvatio da nastupaju nova vremena, da nastaje novo društvo, da je to vrijeme seobe naroda. Takav je bio i kao misionar. Naime, sam ga je kardinal Kristijan August, nadbiskup ostrogonski, nazvao primus et continuus schismaticorum antagonista - >prvi i trajni protivnik šizmatika $\ll^{87}$. To potvrđuju razni slučajevi iz toga razdoblja, kao onaj slučaj sa sugovornikom, pravoslavnim popom, koji ga je pri diskusiji napao i ranio ili kad je obraćao kalvine za vrijeme Rakoczyjeve bune, kad je tekla krv na obje strane. On je u svom južnjačkom žaru previdio da u njegovoj biskupiji živi narod koji se naviknuo na franjevce i njihov pastoral, narod koji je nakon dugogodišnjega života pod turskim terorom jedva dočekao žuđenu slobodu. U dobroj namjeri želio je prebrzo obnoviti razoreno, unaprijediti zaostalo smatrajući da kao vlastelin na to ima pravo.

Bilo je i razloga druge, objektivne, naravi. Kao što je već istaknuto, Bosanska biskupija bila je malena, sa svega četirima župama koje je njegov prethodnik za stalno povjerio franjevcima. Do oslobođenja Slavonije od Turaka redovnici župnici imali su svoj oblik pastorala, stoljećima su se držali svojih pravila, imali su svoju redovničku upravu, iz Rima su dobivali razne povlastice kojih se nisu bili voljni odreći, a narod nije ni čuo da postoje svjetovni svećenici, no kad su se pojavili, smatrao ih je rivalima franjevaca. Dotad je pod turskom vlašću biskup običavao pohoditi župu, podijeliti krizmu i što prije otići dalje. Tijekom stoljeća redovnici su postupali prema svojim »pastoralnim pravima «, na koja su se često pozivali u svojoj pastirskoj službi. Bakić je bio među onima koji su smatrali da je nakon oslobođenja Slavonije od Turaka

\footnotetext{
${ }^{85}$ HR-NAĐ, fond Bakić, kut. Bakić, Querelae contra Dnum Generalem Essekiensem 1728.

${ }^{86}$ HR-NAĐ, fond Bakić, kut. Bakić, Ouo upisagnije, u: Pro usu Conscriptionis, 7.-26.

${ }^{87}$ HR-NAĐ, fond Bakić, kut. Bakić, Testes et Testimonia, 27.
} 
došlo vrijeme za ponovnu uspostavu redovite crkvene hijerarhije s biskupom kao vrhovnim poglavarom mjesne Crkve. Zbog toga je dolazilo do nesporazuma, trzavica, sukoba i sablažnjivih prizora. I biskup i franjevci pozivali su se na svoja prava. I s jedne is druge strane obistinilo se pravilo: Summum ius - summa iniuria - »Najveće pravo - najveća nepravda! «

Neposredno nakon oslobođenja Slavonije vladalo je bezvlađe u kojem je vojna vlast smatrala da je iznad svake druge vlasti, čak iznad duhovne biskupske vlasti. »Njemački vojnici« nisu poštovali ni crkvenu vlast, biskupsku i župničku, jednako su otimali i pljačkali usjeve, krave, konje s biskupskoga vlastelinstva kao i s posjeda siromašnih kmetova ${ }^{88}$ Međutim, uza sve to, primjeri dvojice biskupa - Đure Patačića, Bakićeva prethodnika i Josipa Antuna Ćolnića, njegova nasljednika - potvrđuju i dokazuju da je suradnja moguća. Obojica su živjela u miru sa svojim suvremenicima, i s franjevcima i sa svjetovnom vlašću, pa is podanicima. Obojica su ostavila dobar glas, a Ćolnić je čak zbog svoje plemenitosti, za vrijeme dok je Slavonija bila u plamenu seljačkih buna, imenovan požeškim županom. ${ }^{89}$

\section{Biskup Bakić pod sekvestrom}

Bakićevim protivnicima prekipjelo je kad je on 19. rujna 1727. godine franjevcima nasilu onemogućio sahranu svoga sluge. (Prilog 5.) Tada su se odlučili na zadnji, sinkronizirani udarac. Izaslanici građana Đakova, đakovački franjevci, predstavnici Budrovaca i devet drugih sela iskoristili su biskupovu odsutnost iz Đakova, kad je 1728. godine boravio u Požunu na saboru, i otišli u Osijek u Komorsko nadzorništvo te optužili biskupa vlastelina da i prema njima postupa nehumano, da im otima njihove zemlje i šume, da ih pretjerano tjera na kuluk itd. Postavili su ultimatum: ako se nešto ne poduzme, oni će se vratiti preko Save na turski teritorij. General Joseph Anton Oduyer, zapovjednik Osijeka, i Komorsko nadzorništvo poslali su u Beč izvještaj o situaciji u biskupiji. Ratno vijeće, kome je na čelu bio Eugen Savojski, po mandatu samoga cara Karla VI., donijelo je odluku da se zbog teških, za sve sablažnjivih postupaka i brojnih optužbi protiv biskupa koje su posljednjih godina stizale, a on se nije popravljao, biskup stavi pod sekvestar. To znači da se udaljuje iz biskupije i da mu se zabranjuje prijelaz granice biskupije, da mu se oduzima pravo uprave vlastelinstva, da se nastanjuje u Brod. Ta odluka stupila je na snagu odmah, a biskupu se oduzelo pravo na obranu. ${ }^{90}$ Biskup je apelirao na palatina, reagirao je

\footnotetext{
${ }^{88}$ M. SRAKIĆ, Tužbe stanovnika Đakovštine protiv vojnika osloboditelja, 197.-199.

${ }^{89}$ M. PAVIĆ, Josip Antun Čolnić, biskup bosansko-djakovački (1755-1773), u: GBBS 23(1895.)16, 137.-138.

${ }^{90}$ J. STANIĆ, Brevis Notitia, 71.-72., 73.-76.
} 
njemu u prilog i Požunski sabor, ali bez uspjeha. On je ujesen 1728. godine bio sekvestriran iz Đakova, u koje se nije smio vratiti sve do 1742. godine. ${ }^{91}$

Za vrijeme sekvestra zagrebački biskup prisvojio je brodski kraj za sebe, na što su se svi bunili, ali bez uspjeha, pa sljedećih 50 godina brodski kraj ostade izvan Bosanske biskupije. Pečujski biskup imenovao je Andriju Natalisa, nećaka Luke Natalisa, delegatom za sjeverni dio biskupije, a Andrija Kečkemet imenovan je upraviteljem biskupskih dobara.

Desetogodišnji Bakićev trud počeo je propadati već u prvoj godini njegove odsutnosti. Ostavši bez nadzora, podanici su uništavali livade i pašnjake, sjekli staru šumu i lovili divljač. Provizori su ubirali desetinu za sebe, iz stada otimali konje i poklanjali ih, zanemarivali berbu, krali drva i prodavali ih u Osijeku, nekad se i fizički obračunavali s vlastelinskim namještenicima. ${ }^{92}$

Nije posve jasno gdje je Bakić boravio za vrijeme sekvestra. Matija Pavić smatra da je živio u Brodu sve do 1740. godine, kad se vratio u biskupiju na početku vladavine Marije Terezije, ${ }^{93}$ a Josip Stanić tvrdi da je cijelo vrijeme, sve do smrti, živio u Varaždinu te da mu, iako je više puta molio da se vrati u biskupiju, molbi nikada nije udovoljeno. Četiri godine nakon što je udaljen iz biskupije, Bakić je podnio molbu Eugenu Savojskome, predsjedniku Ratnog savjeta, da smije za Uskrs 1732. godine obaviti uskrsne obrede u Đakovu, ali mu molba nije bila uslišana. ${ }^{94}$ Ipak, on je iz Križovljana upravljao biskupijom i sva su mu pisma bila slana onamo. ${ }^{95}$ Možda bi se ta oba mišljenja mogla prihvatiti da se biskup doista vratio u Đakovo, ali da je često boravio u Varaždinu i na svojem dobru u Križovljanu kamo su mu slali akte iz Đakova. Tamo se družio s Oršićima i Patačićima. Imao je dva nećaka svećenika. Jedan je, Gabro, bio kanonik u Pečuhu († 7. 3. 1737.), a drugi, Antun, kanonik u Nitri († 1745.).

Tri godine nakon što je Marija Terezija svojom odlukom skinula s njega sekvestar i on se vratio u Đakovo, Bakić je doživio novi udarac, tj. osnutak ili, točnije rečeno, reorganizaciju Hrvatsko-slavonske vojne krajine. Naime, rezolucijom Marije Tere-

${ }^{91}$ HR-NAĐ, fond Bakić, kut. Bakić, Copien und Extrakte der Akten des k. und k. Krieges-Archives (17221731) bezugnemend auf Petrus Bakics de Lak quondam Bischof von Bosnien; Copien von Akten des k. und k. Reichs-finanzministrums (1728-1748) bezugnemend auf Petrus Bakics de Lak quondam Bischof von Bosnien.

${ }^{92}$ HR-NAĐ, fond Bakić, kut. Bakić, Querelae Contra Dnum Generalem Essekinensem A. D. 1728. Pritužbe kapelanâ biskupa Bakića Ivana Pavla Mesarića i Martina Paluha. J. P. MESSARIUS, M. PALUH, Damna illata Dno Eppo Anno Dni 1728.

${ }^{93}$ M. PAVIĆ, Petar Bakić, Biskup bosansko-djakovački (1716. - 1749.), 208.-209.

${ }^{94}$ HR-NAĐ, fond Bakić, kut. Bakić, A 'Sua Al. Ser.ma il Principe Eugenio di Savoya.

95 J. STANIĆ, Brevis Notitia, 15.-16. 
zije od 6. travnja 1745. godine od posjeda đakovačkoga biskupa oduzeto je sedam sela i posjeda oko njih i pripojeno Vojnoj krajini. To su Mikanovci, Strizivojna, Vrpolje, Čajkovci, Andrijevci, Perkovci i Topolje; ta su sela imala 64 sesije i 694 jutra šume. Na odcjepljenju tih sela i posjeda inzistirao je grof Kolovrat, onaj isti koji je Bakića odstranio iz Đakova. Biskup je reagirao i protestirao, ali bez uspjeha. ${ }^{96}$ Uspostavom Vojne krajine nisu bili zadovoljni ni svi stanovnici oduzetih sela, osobito Perkovaca, pa su na vrijeme napustili svoje domove i preselili se na biskupsko vlastelinstvo i tu osnovali Nove Perkovce.

Kad je već ostarjeli biskup vidio da mu je uzaludno tražiti sela natrag, zahtijevao je da mu se plati odšteta od 59697 forinta i 7333 forinte kamata. Komora mu je priznala pravo na nadoknadu, ali mu je ponudila samo 30593 forinte, dok mu je barun von Engelshofen predlagao doživotnu rentu od 949 forinta godišnje. Bakić se obratio kraljici 23. svibnja 1748. godine, a ona je naredila da se međaši reguliraju in facie loci, ali se to nije stiglo učiniti za vrijeme biskupova života. Naime, biskup Petar Bakić umro je 5. srpnja 1749. godine u Križovljanu u 79. godini života. Pokopan je u mjestu koje ni ne zna da među njima počiva bosanski ili đakovački biskup, u župnoj crkvi koje više nema, u grobu koji je sravnjen sa zemljom. ${ }^{97}$

\footnotetext{
${ }^{96} \mathrm{NAĐ}$, fond Bakić, Bakić, Dopis od 16. prosinca 1744; 1. siječnja 1746.; 23. siječnja 1748. i 29. lipnja 1749.; M. PAVIĆ, Petar Bakić, Biskup bosansko-djakovački (1716. - 1749.), 207.-208.

${ }^{97}$ E. GAŠIĆ, Brevis conspectus historicus, 38.-39.
} 


\section{PRILOZI}

1.

\section{Biskup Bakić o vinogradarstvu u Đakovštini za vrijeme Turaka ${ }^{98}$}

»Vinograde u ovomen atharu lipe Turčin imadoše, u koizi dobro vino rastaše, koje sada od onoga vrimena sva jesu obatalila. Izvan onizi koje Pokojni Biskup za sebe zauze navlastito u Sterbinci vinograd Ali Baše, koji jest od motika dvaest i pet, drugi vinograd na Vitiki rečeni koji jest bio Ibraim Čiehije, od motika deset, treći vinograd tolikojer na rečenom Vitiki, kojeg je bilo nikojega Turčina Graskoga Hoše (hodže), od motika deset. U Vučiaku tolikojer zauze dva vinograda, jedan bijaše nikojega Turčina Tufežije Ibraima od motika deset, drugi bijaše Turčina Kurteš Alijin od motika osam, koji i sada svi se radu(ju). Dobro vino u svim raste po oka 1400, koji vinogradi jesu sada svi zauzeti na stranu svitle komore dvorjanske. Ostali vinogradi svi jesu opušćeni, veće ovo godište nikoji kmeti iz Budrovac pričeše loze saditi, budući vinogradi neposlovani jali zapušćeni okolo dvi stotine jutara, dico 200 .«

2.

\section{Zakonik biskupa Bakića}

\section{Izvorni tekst Zakonika}

\section{Ono upisagnije dase mose, na pame-} ti darsati, niti drugaçie uçiniti ${ }^{99}$

Paruo. Kadase bude ù fate zapouidalo, uozit ù Ossich, aliti, nà Fosponte, dà oua Sela oude upisana imadu slobodna biti, à tosu sela Podgorije, Borouich, Pounçie, nechie ona raditi na Kreçani, szua sto kodise gnioma bude potriboualo dohlamçe sasgu, ij szuarse reçene.

Drugo. Koi budu kopali ij szue ostalo dilo od Vinograda, ù Tarnaui poslouali ij çinili, da budu prosti, Fati Ossischi, Gaschi ij Beçiluka, a to iesu oua tri Sela, Tarnaua, Szuetoblasije, ij Kondrich, koi Tarnauschi Vinograd mogu poslouati.

\section{Zakonik na suvremenom hrv. jeziku}

Neka se ova odredba zapamti i neka se drukčije ne čini

Prvo. Kad se bude zapovijedalo voziti drva u Osijek ili izgrađivati nasipe za mostove, neka ova sela, ovdje upisana, budu toga oslobođena, a to su sela: Podgorje, Borovik, Paučje. Već će ona raditi na krečani, sve što god bude potrebno, dokle ne sažgaju i svrše rečeno.

Drugo. Koji budu kopali i obavljali sve ostale vinogradarske poslove $\mathrm{u}$ vinogradu u Trnavi, neka budu oslobođeni od osječkih i gradskih fati (prevoženja drva) i desetine, a to su ova tri sela: Trnava, Svetoblažje i Kondrić, kako bi mogli raditi u trnavačkom vinogradu.

\footnotetext{
${ }^{98} \mathrm{NAĐ}$, fond Bakić, BAKIĆ, P., Pro usu Conscriptionis, str. (s.d.)

${ }^{99} \mathrm{NAĐ}$, fond Bakić, tresor, BAKIĆ, P., Pro usu Conscriptionis, 11.-24.
} 
Trechie. Da Priduorçi, budu slobodni, od Fati Ossischi, zasto da oni imadu kopati, snasiti, dilati, çuuati Vinograde Priduorsche namisto Fati.

Çetuarto. Vinograde koje imadu sela kopati ij - raditi, da budu slobodni Fati Ossischi à to iesu Vinogradi, Starbinaçz, Golisauaçz ij Vuçniach, ona tri Sela Gausinçi, Prestlatinçzi, ij Dargnije, schupe megusobom razdilit ter snasiti.

Peto. Varoš Diakouaschi, da bude slobodan od fati Ossischi, ij Graschi, namisto koizi fati mogu led uoziti ù Ledeniçe, ij Basçu kositi schupa, ij pliti, snasiti, sto bude potribno Basçokanu stime Beçiluch u Grad dauati poradi toga ozgora imenouana budu prosti uoziti reçene fati.

6. NB. Szua Diakouschina moze dobro znati, da od sada, nikomu neimadu kakuu maruu prodati, uechie mesaru, iali Kasapu Gosposkome, za neka Varos mose, ù szuako urime od Godista ij Voijniki sputniki mesa imiti, à Kasap bude kakose marse procini platiti szuakome prez szuakoga spriçagnia.

7. Da se neima nikome drugome prodati, med, uosach, Vino, Rakia, uechie samu Gradu Gosposkome à budese szuekoliko plachialo po onu cinu kakono drugi budu prodauali, ij kupouali

8. Dase za Grad Gosposchi imade pod iesen maslo nositi po starom zakonu, obiçaiu ij nauadi, rekuchi dusnosti, od szuake sesie po iedna ocha, tolikoier, po isti naçin po jedna ocha pregie od szuake sesie opregiene, à ne ukudij.
Treće. Neka Pridvorci budu oslobođeni od prevoženja osječkih drva, ali zato umjesto toga imaju kopati, održavati, raditi, čuvati pridvorske vinograde.

Četvrto. Sela koja imaju kopati vinograde, neka budu oslobođena od prevoženja drva u Osijek, a to su Vinogradi, Strbinac, Goliševac i Vučjak, te tri sela Gašinci, Preslatinci i Drenje, koja neka (brigu za vinograde) među sobom razdijele i snose.

Peto. Varoš đakovački neka bude slobodan od prevoženja osječkih i gradskih drva, a umjesto toga mogu voziti led u ledenice, skupa kositi i plijeviti vrt, donositi što bude potrebno vrtlaru i time desetinu u grad davati. Radi toga, gore imenovana (varoš) neka bude oslobođena prevoženja rečenih drva.

6. NB. Cijela Đakovština neka dobro zna da odsad nikome ne imade kakve marve prodavati, ni mesaru ni gospodskome mesaru. Neka varoš u svako doba godine može vojnicima putnicima meso iznijeti. A mesar, kako se marva (životinja) procijeni, neka naplati svakome, bez ikakva izuzetka.

7. Neka se nikom drugom ne prodaje med, vosak, vino, rakija, već samo gospodskome gradu; a sve neka se plaća po onoj cijeni po kojoj budu drugi prodavali i kupovali.

8. Neka se u gospodski grad ujesen maslo nosi po starom zakonu, običaju i navadi, odnosno dužnosti, od svake sesije po jedna oka, također na isti način jedna oka pređe od svake sesije, opredena, a ne u kudjelji. 
9. Da imadu szua Sela priko godista, kolikojest nediglia ù gniemu, nositi ù $\mathrm{Dja}$ kouo nà piacu, sto kodi ima na prodaiu, kokose, pilichie, maslo, sir, Purane, Gusche, Patche, slanine, Boba, Graha, Soçiua, szuakoiaska luch ij ostala szuakolika, kakonose dostoij, ter nauada iest, po drugi Vilaeti, ij Varosi. Takoier ribu, rake, zabe, slouinom ostalom.

10. Diakouuci dobro mogu promisliti, koliki se quari, ij steta Kanuuge (?), szuignije, çine radi steta koiese pò poiu szuaki dan uide, ij nahagiau; da tolike Tusbe prid nasz dohagiau, uidechi razmisglieuaiuchi, taman uprauiti, da unapriedach, nitko neima orati, siati oue ieseni nà dui strane, negoli szui schupa od Varosa na iednu stranu orati, ij siati mogu po nauadi starom.

11. Szui schupa mogu znati, kolikose darua imade nositi nagodinu ù Ossich, Klaftri tuardi, ij mekani za Ciglanu, prez daruua Graschi, atoije ù Diakouo za forune, Kuigniju, Strase Voijnische ij Bandursche, prez pristancha rekuchi siednom riçi.

12. Darua za Grad szua sela redom mogu uoziti kolikoi, bude odpotribe, tolikoier, za mestriu, ij za plote, Stobore, palizate, Kuchie moste, etc. iednom riçi rekuch szuaka potribita Gosposkome Gradu.

13. Da imadu szua Sela Kreç, ij pisach za Grad uoziti prez szuakoga spriçagnija, Cigal, Kamen sostalima koija budu od potribe, prez onizi Sela, koi radu na Kreçani, ij Vinograde da budu prosta, nechie rakiu zgati, à to ona koija Vinograde rade da rakiu imadu pechi.
9. Neka sva sela preko godine, koliko je u njoj nedjelja, nose u Đakovo na pijac što god imaju za prodaju, kokoši, piliće, maslo, sir, purane, guske, patke, slanine, boba, graha, sočiva, svakojaki luk i ostalo kako se dostoji i običaj jest po drugim pokrajinama i varošima. Također ribu, rakove, žabe, s ostalom lovinom.

10. Đakovčani neka dobro promisle koliko kvara i (...) (?)svinje čine, radi šteta koje se po polju svaki dan vide i nalaze; da tolike tužbe pred nas dolaze. Videći i razmišljajući (o tome), upravo sam odredio da unaprijed nitko ne smije orati, sijati ove jeseni na dvije strane, nego, po starom običaju, mogu svi skupa orati i sijati od Varoši na jednu stranu.

11. Svi znaju koliko se drva godišnje treba voziti u Osijek, hvati tvrdih i mekih za ciglanu, bez gradskih drva, a to je u Đakovu za peći, kuhinju, vojničke i pandurske straže, bez oklijevanja, bez ijedne riječi.

12. Drva za grad sva sela mogu redom voziti koliko bude potrebno, također za obrte (meštriju) i za plotove, stupove, palisade, kuće, mostove, itd. Jednom riječju, sve što je potrebno gospodskome gradu.

13. Neka sva sela, bez ikakve isprike, voze u grad kreč i pijesak, ciglu, kamen i ostalo što bude potrebno, a ona sela koja rade na krečani i u vinogradu neka budu slobodna za pečenje rakije, to jest ona koja obrađuju vinograde neka peku rakiju. 
14. Da susidi od Tarnaue iali blisnia sela imadu pomochi targati, ij voziti most od reçenoga uinograda, Kakono Gospoda budu zapouidala da mose biti.

15. Da szua Sella kadase bude zapouidilo, ili u fate uoziti schupa nista neodulaçechi otichi ter dusnost izuarsiti, sto prie to boije.

16. Szua Kolika Sela prez onizi zgora imenouani mogu fosponte dauati, sino, zob, darua ij Voijache, na Quartiru darsati ij raniti po nauadi dosada dobro znanom. Toligoier Elçie, iali Voijniche, ij Gospodu uoziti sprofuntom po praudi szuachi.

17. Da szuako Sello, za goda imade Portie Szuhartiri Kupiti, nositi, à neçekati Csekutie doklam doijde.

18. Da szua Sela imadu palizate Voziti, ij naprauijati Okolo Grada prez onizi sella koia uinograde ij Kreçane radu.

19. Da szua Sella kadabi bilo od potribe, Xito uoziti na Vodenicze, kamo bimuse zapouidilo, postarom obiçagniu ij nauadi nositi mliti.

20. Dabise Sella smislila za moije trude, arçe, uçigniene ù toliko puta odechi ù Osich, za izbauit od Saraluka, nakoi, do moiega dosaschia, iesu dauali, po stotinu iudi po szue Godiste, ù zimi ij litu, nigdi nepristausi, szuetha, zime, Kise, Vruchine, aliti nepouoijna urimena, Smislilise na tò ter Sella mogla meni szua schupa nikoliko utarpati, zita, jeçma, prosza, zobi, kakono su mi obechiali, kakonosumi obechiali, kadasu slobodni bili od toga Saraluka, od szuoije dobre uoije.
14. Trnavački susjedi, ili bliža sela, neka pomognu brati (trgati) i voziti mošt rečenog vinograda kad gospoda to budu zapovijedala.

15. Neka nijedno selo, kad bude što zapovjeđeno, ili treba zajednički odvoziti drva, ništa ne odugovlači, već ode i izvrši, što prije, to bolje.

16. Sva sela, osim gore imenovanih, mogu davati fosponte, sijeno, zob, drva, a koji hoće (mogu) na kvartiru držati i hraniti vojnike. Također, poslanike, vojnike ili gospodu voziti besplatno, po pravdi svakoj.

17. Neka svako selo godišnje ima porcije sunartiri (?) kupiti, nositi, neka ne čeka da dođu ovrhe.

18. Neka sva sela voze palisade da se stave oko grada, osim onih sela koja rade $u$ vinogradima $i$ krečanama.

19. Neka svako selo, kad to bude potrebno, vozi žito mljeti na vodenice kamo mu se zapovjedi, po starom običaju i navadi.

20. Za moj trud i troškove izdane za odlaske u Osijek da oslobodim od desetine (šaraluka), za koju su do mojega dolaska davala po stotinu juda (?) godišnje, zimi i ljeti, bez prestanka, svetkom, po zimi i kiši, po vrućini ili nepovoljnom vremenu, neka su sela dobrovoljno smislila da bi mi za sve skupa mogla posijati nekoliko jutara žita, ječma, prosa, zobi, kao što su mi obećala kad su bila oslobođena od te desetine. 
21. Sela nochu rana za Grad imadu nositi prez szuakoga opominka po starom nauadi ij obiçaju.

22. Da szuacho selo za urimena imade Gumna za Gosposcha žita naprauijati, szuesti, pokriti, oplesti, izuarsiti, donesti, schupa sonime, koi bude nato pogled imao od Gosposche strane poslani à slamu lipo sprauiti, pokriti, oplesti da nebi ustetu otišla, nechie asan, da se mose uzeti. A Sluga, iali Bandur, illiti Katana, koi bude nato postauien dohlam onde na çuuaho, damu Selo mose dauat ranu po nauadi starom.

23. Dase Knez imade izbirati, Çouich Spametan zamomoch, znati selom uprauiti, ij putniche Szuoijniki nastaniti po moguchiu seoskome kakose bude moglo, koiega izabrauši, od maha Gospodi prikazati ochieliga, ij datimu oblast Selom uprauiati.

24. Da Sello na beçiluch, iali saraluch neimade Diçu posiati, uechie musche glaue, koieno iesu za dilo takuuo, mignije Starçe, niti Bolesnike, koi niti sebi, niti drugome mogu poslouati, iali raditi.

25. Da Knez bude, od szuakoga posla, dachie quartira beçiluka, beçiluka, daruarine, fosponta, quartira slobodan. sportiom: koiega Szue Sello, imade slusati, postouati, Darsati, za Poglauara szuoiega namisto Gospodina buduchi stit Gosposchi iali iz ruka Gosposcha, ter, koi nebiga poslusahò, à mi izuznali çinimoga szuezana douesti, ij datimu sto paliçija perui put, drugi put sto, ij birsaga platit duanaieste forinti, trechi
21. Sela imaju donositi hranu za grad, bez ikakve opomene, po staroj navadi i običaju.

22. Svako selo treba na vrijeme napraviti, svesti, pokriti i oplesti guvno za gospodsko žito, ovršiti ga i donijeti skupa s onim koji bude za to od gospodske strane poslan. A slamu lijepo spraviti, pokriti, oplesti da ne bi propala, već bila na korist, te da se može uzeti (upotrijebiti). A slugi ili panduru ili katani koji bude postavljen da to ondje čuva, selo može davati za to vrijeme hranu, po staroj navadi.

23. Neka se za kneza izabere čovjek sposoban, koji će moći i znati selom upravljati i smjestiti putnike vojnike, prema mogućnosti sela, kako se bude moglo. Nakon izbora treba ga odmah predstaviti gospodi koja će odlučiti hoće li mu dati vlast da upravlja selom.

24. Selo ne smije pozivati djecu na radove $\mathrm{u}$ ime desetine (bećiluk ili šaraluk), već muške glave koje su za takav rad, također ni maloljetnike, starce i bolesnike koji ni sebi ni drugome ne mogu poslovati ili raditi.

25. Neka knez bude slobodan od svakog posla i davanja desetine (bećiluka), drvarine, izgradnje nasipa za mostove (fosponta), kvartira. Njega sve selo ima slušati, poštovati, držati za svoga poglavara namjesto gospodara. On je štit gospodski ili produžena ruka gospodska, zato ćemo onoga tko ga ne bi poslušao, a mi to budemo saznali, dati svezana dovesti i dati mu sto udaraca batinom (palića) prvi put, drugi put sto 
put, ù Ossich poslat sançati, dase mose nauçit postouati, ij slusati poglauare szuoiega Sella, a Gosposchoga namisnika.

26. Od Bandura mose szuachi znati, da imade biti slobodan siednim bratom iliti soçem, szuoizim, od szuasta, kakonosu dosada bili, à Druga Brachia, iali sinoui, uchoiom bise uise Muschi glaua naslo, da imadu upomoch od szuasta stabise na gnione glaue dostoialo, Selu dauati pomagati, kakono ostala, Brachia ij drusina daiu ij pomagaiu reçenome Sellu. Vise toga, koibi Bandur priuse drugoga zemgliu, aliti pustoselinu izuan oçeuine, da odgnie ima plachiati, kakono Drugi od reçene prie iest plachiaho, nakoie szuakom praduua.

27. Katane, Haijduçi, ij szue ostale Sluge Gosposche, da iesu slobodne od szuakoije dachie, portie kakonosu ù szuakoie urime bili prosti, tako ij sada ù szuako urime od danasnega Dneua da to bude szuima, ij szuakome dobro znano.

28. Kadase bude portia rizat, dase imade nasuasto rizati odstase koi pomase / izuan Vinograda/ Na Glaue, Brachiu, Sinoue, Çobane, Basçe, Vodeniçe, Kazane, Xito, Çaiere, pçele, Maruu, Vole, Ovce, Koze, Prasce, zemglije, Çaiere, samo dase nerise, na zemglije neorane, iali neposiane, neuzimiuch od gni asne nikague tako od reçeni ništa plachiati. Dase na Gazde iliti Poglauare od Kuchija iednako rise, toliko nà Bogato, Koliko nà ubogo.Na Brachiu mignije koisu momki, Osegneni, iati za oseniti, à nà druge ioste udaraca i za kaznu (globu) platiti dvanaest forinti, treći put u Osijek poslati sančati (?), da se nauči poštovati i slušati poglavara svojega sela, a gospodskoga namjesnika.

26. Svaki pandur neka zna da s jednim bratom ili svojim ocem može biti oslobođen od svega,, kao štosu i dosad bili. A druga braća ili sinovi, tamo gdje bi se više muških glava našlo, neka budu od pomoći u svemu što bi na njihove glave spadalo, selu davati, pomagati kao što ostala braća i družina daju i pomažu rečenome selu. Osim toga, pandur koji bi preuzeo zemlju drugoga ili pustopoljinu, izvan očevine, morao bi od nje plaćati, kao što su i drugi prije njega plaćali, tako nalaže pravda.

27. Katane, hajduci i sve ostale gospodske sluge neka budu slobodni od svih davanja i poreza, kao što su u svako vrijeme bili oslobođeni, tako i sada, da to bude svima i svakome dobro poznato.

28. Kad se bude određivao porez, neka se određuje za sve od čega netko živi /osim vinograda/. Na glave, braću, sinove, čobane, vrtove, vodenice, kazane, žito, zemlju, livade, samo da se ne razrezuje na neorane ili neposijane zemlje, jer od njih nema nikakve koristi, tako odrečeni (otkazani) ništa ne plaćaju. Neka se na gazde ili poglavare kuća jednako razrezuje i na bogate ina uboge. Na mlađu braću koja su momci, oženjeni ili su za ženidbu, a na druge još i manje, također na malo čobanče još 
mignije, tolikoier, nà malo Çobançegnije ioste mignie, zà neka szuakome prauo bude, dase nitko nemose tusiti nà nikoga, ni dechi iakost szuakoga

29. Udouuicam ij Sirotam dase neima koia Kriuicza uçiniti, iali ucuiliti, zato imiè za dosta cuilegnia, ù neuoij Sirotinstuom ostati zasto da nebi sirota bilo, nitibi suncene mi suitlosti mogli imati, nechie zaradi gni, sunce nas zgrie, uchom ije, szua nasa radost.

30. Koi Starci nemogu ù Selu za sebe raditi, nemoguse slati na beçiluch, Saraluch, fate, niti na drugo dilo tomen spodobno.

31. Nimçe raniti, kako Selo bude uidilo ij znalo koiu Kuchiu, iaxu, tolikoier sino, ij zob dauati, po ti naçin Goste putnike, nastan primati kakose bude selu uidilo, da za boije bude, tako çiniti achobi koi drugaçie otio uçiniti, ter neposlusaho Kneza, bude sto paliçija primio ij Gospodi Birsag platio.

32. Kadase bude koija Kuchia diliti dase zoue Knez od Sela, ij dua druga sgnime spametna Çouika, koi mogu prez szuakoga mita iali dara prao razdiliti nech prie za Gospodu Vola izabrati, po nauadi obiçaija, ter acho Knez nebi toga uçinio, da prime nadar sto paliçija, ij szuoga Vola dade Gospodi za Birsag. -

33. A kadase bude koi zenio ter daroui saszuom szuadbom uise budu stali od çetiri, aliti pet forinti birsaga plati Gospodi duanaest forinti, ij paliçije prime, koiakkoija szuadba neima uise tarpiti, od iednoga ruscha prez Szuatova, Bariacha, kola bubgnia ij szuirala, zasto da dru- manje, pa neka svakome bude pravo, da se nitko ne može tužiti nina koga, kad vidi jakost svakoga.

29. Neka se ne čini nikakva krivica ili naudi udovicama, sirotama, jer im je dosta plača (cviljenja), u nevolji sirotinjskoj ostati, jer kad ne bi bilo sirotinjskih nevolja, ne bi mi mogli imati sunčeve svjetlosti, jer zbog njih nas grije sunce $u$ kom je sva naša radost.

30. Starci koji ne mogu u selu za sebe raditi, ne mogu se slati na radove $u$ ime desetine (bećiluk, šaraluk), voziti drva, niti na drugi posao, makar i bili sposobni.

31. Nijemce hraniti kako selo bude vidjelo i znalo, koju kuću, i zgradu, također sijeno i zob davati. Na taj način goste, putnike, na stan primati, kako se bude selu činilo da je najbolje, neka tako učini. Ako bi tko htio drukčije učiniti, i ne poslušati kneza, neka primi sto udaraca, a gospodi neka plati globu.

32. Kad se bude koja kuća dijelila, da se zove seoski knez i dva druga pametna čovjeka s njim, koji mogu bez ikakva mita ili dara pravo razdijeliti, i nek najprije za gospodu vola izaberu, kako to nalaže običaj, a ako knez ne bi toga učinio, nek primi na dar sto udaraca, $\mathrm{i}$ svoga vola dade gospodi za globu.

33. A kad se bude tko ženio, temu darovi sa svom svadbom budu stajali više od četiri ili pet forinti, platit će gospodi globu od dvanaest forinti i udaraca batinom, a svadba koja nema većeg troška od jednoga ručka, bez svatova, barjaka, kola, bubnja i svirala, ako drukčije uči- 
gaçie uçini, bude Gospodi birsag platio, od forinti 12 ij paliçije imaho na poklon. 34. Koibi zamahnuo, na Brata Stariega, prime sto paliçija, akoli udario, prime paliçie ij bude poslan ù Ossich.

35. Koibi zamahnuo na Ocea, iali Mater, çinimuse ruka osichi, achobi udario glaua po zakonu Vilaieta.

36. Kibise nasaho, da sagrisi schakouom bestiom, ziuinçetom sasgan bude skupa na uatri.

37. Koiemubise oçitoualo /:izuan izpouidi:/ daie sagrisio, iali sagrisila, zblisnim szuoim Rogiakom, iali rodicom budu obadua sasgana na uatri.

38. Koibi sproti Bogu proklignia, ij szuetima Bosjijima budemuse iezich zivu na zatilach izuadio poslie glaua osichla od Xuchara đelata.

39. Koiemubi Xena odbigla, prez uelika uzroka, bude utarlicu na piaczu postauiena, za tri nedie da uasz puch gledagnie sramotu, ondne nastoiechi.

40. Koibise nasaho da dui Xene ima, aliti Xena dua Musa, bude na dui polouine rasiçen od zelata.

41. Koibi Paho prokaruario drugoga szuadiunsase, Gospodi Birsaga plati, tri forinta, à onomen tri kogaije prokaruauia.

42. Koi Pahor tahoua izbie, ter doijde tusiti Gospodi plati birsaga talir parui put, drugi put, tri forinta ter bude arestan u Gradu sancati. ni, platit će gospodi globu od 12 forinti i dobiti batine (paliće) na poklon.

34. Tko zamahne na brata starijega, primit će sto udaraca, a ako bi udario, bit će izbatinan i poslan u Osijek.

35. Ako bi tko zamahnuo na oca ili mater, po zakonu pokrajine odsjeći će mu se ruka, a glava ako bi ih udario.

36. Tko sagriješi s kakvom beštijom, živinčetom, neka bude spaljen skupa $s$ njom na lomači.

37. Kojemu bi se dokazalo/:izvan ispovijedi:/ da je sagriješio $s$ bližnjim svojim rođakom, ili rodicom, neka budu oboje spaljeni na lomači.

38. Koji bi Boga proklinjao, i svece Božje, bit će mu živom jezik na zatiljak izvađen, a krvnik mu poslije glavu odsjeći.

39. Kojemu bi žena odbjegla bez velika razloga, neka bude stavljena u klade (trlicu) na pijacu, da ondje stojeći tri nedjelje sav puk gleda njezinu sramotu.

40. Koga bi se otkrilo da ima dvije žene, ili žena dva muža, neka bude na dvije polovine rasječen od krvnika.

41. Koji bi pak raskrvario drugoga svađajući se, neka gospodi plati tri forinte globe, a tri onom koga je raskrvario.

42. Koji pak drugoga izbije, a bude tužen gospodi, platit će talir za globu prvi put, drugi put tri forinte te biti bačen $u$ gradsku tamnicu. 
43. Koibi guar drugome uçinio, da Tuszi Knezu, ter ide ioste siednim, iai zduama prociniti guar, ter da plati zdobrim acholi nebi, tusiti Gospodi koiom plati talir birsaga ij stetu stoije uçinio Çouichu.

44. I tem koi nebi pokoran bio platiti zdobre uoglije, onada plati duastruch quar, iali stetu uçignienu, à Gospodi talir Birsaga.

45. Koibi Szuigniami pokuario Çaiere dase çini prostimati kako zgora iest reçeno, acholi zdobrim nebi otio platiti, onada Gospodi plati talir birsaga, à onomen quar koiemuije uçinio.

46. Koibi plot prolomio drugome, terse steta na onu prilazu uçinila, da oni plati koije prolomia szuu stetu onu.

47. Koibi zatiaho kakuu desetinu szuete Matere Crikue onoga nitko nemose izpouiditi à Gospoda izuznausa szue koliko ù Begluch uzmu, à gniemu çine dati sto paliçia napoklon.

48. Koi nebi dosaho na peçat Gosposchi, iali na znagnije, da ima platiti parui put, iedan talir, koi drugi put, tri forinta, ij prime paliçije nadar.

49. Koibi otio Gospodu izuesti na usce gledati hoc est ad faciam loci, da prigleda tada ima platiti strosach Gospodi ij duanadeste forinti, A koibi izueo Koiega drugoga Oficira, dademu strosach, ij dua forinta za gniegouu trud.

50. Acho bi Selò znalo za iednoga zla Çouika, ter ga Gospodi nekazalo, iali neufatiuusi donelo, da Knez bude u
43. Koji bi nanio štetu drugome, da se tuži knezu, koji će još s jednim ili dvojicom procijeniti štetu, koju neka plati dobrovoljno, a ako to neće, tužit će ga se gospodi kojoj će platiti talir globe i štetu što je učinio čovjeku.

44. Koji ne bi bio spreman platiti dobrovoljno, neka plati dvostruko za počinjenu štetu, a gospodi talir globe.

45. Koji bi svinjama pokvario livade, neka se s njim postupi kako je gore rečeno, ako dobrovoljno ne bi htio platiti, onda će gospodi plati talir globe i namiriti štetu onome kojemu je zgriješio.

46. Koji bi plot polomio drugome, te učinio štetu na prilazu, nek plati svu štetu koju je prouzročio.

47. Onoga koji bi zatajio kakvu desetinu svete matere Crkve nitko ne može ispovjediti, a gospoda će mu, saznavši za to, sav begluk oduzeti, a njemu dati sto batinana poklon.

48. Koji bi se oglušio na potpis gospodski ili na poziv, ima platiti prvi put jedan talir, drugi put tri forinte i primiti batine na dar.

49. Koji bi htio gospodu izvesti na uviđaj hoc est ad faciam loci, da pregleda, tada ima platiti gospodi dvanaest forinti troška. A koji bi izveo kojega drugoga oficira, plaća mu dvije forinte troška za njegov trud.

50. Ako bi selo znalo za jednoga zločinca, a ne bi ga gospodi prokazalo ili uhvatilo i dovelo, neka knez bude u lan- 
guozgie zakonom ij praudise prida ù ruke, daga sude stoie zaslusio da prime plachiu, à Sello Gospodi duanadeste forinti plati Birsaga.

51. Dase Xena Schurba, ter Selo megiusobom nepokara, à Gospoda izuznadu Bude Sello birsag platilo, à Knez dobro palicije ioshie dostati.

52. Kobi zemgliu szuoiju posiaho, ter mogao ioste uise posiati, à nema uise szuoije zemglie, onada slobodno drugoga zemgliu, koiubi nasao praznu, à da çigouaije nemose posiat, tako oni koi mose dase pomoseosan Gospodi, ij onomen koi posie /:Alise to mose razumit, da nebi koiu zemgliu szuoiu goru ostauio ter drugoga boiu prifatio / neka szuachi szuoie snosi à nepribire po Sellu zemglije, niti drugoga prima, sta nebi niti gniemu drago bilo, dabi koij gniegoue pribirao.

53. Da imade szuaki szuoije zemglije, ij Çaiere, çistiti, snasiti, ter koi nebi snasio, bude birsag Gospodi platio, à zemia se drugome dade, koi bude mogao snasiti ij çisto darsati.

54. Achobise koi iz daleka naselio, izprich Saue, Draue, iali od Temisuara, onomense bude sloboda dala za dua godista, portie, Beçiluka, quartira, Saraluka, ij Nimaschoga, quartira, ij daruarine Osische, ali budu mogli od suasta desetinu plachiati, Szuetom Materi Çrikui.

55. Koibise nasaho da Kriuo szuidoci tesach birsag bude platio parui put ij tescho paliçije podnesao, à koi drugi put gniemu od enkara bude iezich izuagien, na zatilach, szuakome to budi napameti. ce okovan i pravdi predan u ruke da ga osude na plaću kakvu je zaslužio, a selo plati gospodi dvanaest forinti globe.

51. Ako se žena prostituira (šurba), te ju selo zbog toga ne ukori, a gospoda to saznaju, selo će platiti globu, a knez biti dobro izbatinan.

52. Koji bi zemlju svoju posijao, te mogao još više posijati, a nema više svoje zemlje, onda može slobodno posijati neobrađenu zemlju drugoga, koji ju sam ne može posijati, to je na korist osim gospodi i onome koji posije /: Ali to podrazumijeva da nitko ne ostavlja svoju lošiju zemlju kako bi se prihvatio bolje zemlje drugoga:/ neka svaki svoje snosi, a ne prisvaja po selu zemlju niti tuđe uzima, jer ne bi ni njemu drago bilo kad bi netko njegovo prisvojio.

53. Svatko ima svoju zemlju i livade čistiti i snositi, a koji ne bi to činio, platit će globu gospodi, a zemlja se dati drugome koji će o njoj brinut i uredno ju održavati.

54. Ako bi se tko izdaleka doselio, preko Save, Drave ili od Temišvara, neka bude oslobođen dvije godine poreza, desetine i radova u ime desetine, te njemačkog kvartira i drvarine osječke, ali će plaćati desetinu Svetoj Materi Crkvi onako kako budu mogli.

55. Koji bi se našao da krivo svjedoči, platit će veliku globu prvi put i biti teško izbatinan, a drugi put će mu krvnik jezik izvaditi na zatiljak, neka to svakome bude na pameti. 
56. Koibi Çouich obolio, ter nemogao sebi, ni drugome raditi on iest slobodan, doklam ozdraui, szuega beçiluka Saraluka, ij drugoga takouua dila, mignie u to vrime od bolesti, mose namisto sebe drugoga naimati, zastomuije zadosta neuoije, ù bolesti lesuchi, çekaiuchi polaxice koije od bolesti.

57. Koibise Momach nasaho ù slusbi, iali ù nauku, od kakoua zanata, iali mestrie, gniegoua Kuchia namisto gniega, nista nemose plachiati, iali obslusevati, doklamse nepourati na suoiu domouinu.

58. Koibi Çouich otisaho na put, za szuoij dobitach, iali targouinu, gniegoua Kuchia dusna iest szueono obslusiti, stobi on mogaho, acholi nebi Kuchia mogla ono obslusiti, tako on, kadase pourati s puta szuoiega, mose szuoiem selu obarsiti, ter isprauiti szuoiu dusnost, stoije zaostaho.

59. Koibi Çouich otisaho po poslu Seoskome, mosemu Sello dati arçe, ij pouuratitimu one dneue koie iest, zaostaho od szuoije kuchie, neradechi, mignije neprigledaiuchi szuoga siromastua.

60. Koibi Çouich, iali Xena, prez oduitka souoga szuita priminula, da Knezoui szuakoija imadu zapriti, zadarsati, doklame Gospodi naznagnije dade, dase nebi sto moglo prosuti, razgrabiti, aliti kamo stauit, zastochie Knez, tescho mah nà szua potanko raçun dati, ij birsag platiti Kesom ij ziuotom.
56. Čovjek koji bi obolio, te ne bi mogao ni sebi ni drugome raditi, oslobađa se dokle god ne ozdravi svih desetina, radova u ime njih i drugih takvih djela, $\mathrm{i}$ može za to vrijeme bolesti umjesto sebe drugoga unajmiti, jer mu je dovoljna nevolja da bolestan leži čekajući neko olakšanje.

57. Koji bi se momak našao u službi, ili u nauku od kakva zanata ili meštrije, njegova kuća umjesto njega ništa ne može plaćati ili opsluživati, dok se ne vrati u svoju domovinu.

58. Koji bi čovjek otišao na put radi svog dobitka ili trgovine, njegova je kuća dužna opslužiti sve ono što bi on morao, ako pak kuća ne bi mogla to opslužiti, tada on, kad se vrati u selo sa svoga putovanja, mora izvršiti svoju dužnost te nadoknaditi što je zaostalo.

59. Koji bi čovjek otišao po poslu seoskome, može mu selo platiti trošak, nadoknaditi mu one dane koje nije radio izbivajući od svoje kuće, ne obazirući se na svoje siromaštvo.

60. Koji bi čovjek ili žena bez oporuke preminuli s ovoga svijeta, knezovi imaju sve zaprijeti (zatvoriti), zadržati dok se o tome ne obavijesti gospodu, da se ne bi što moglo prosuti, razgrabiti, ili negdje odnijeti, za što bi knez snosio tešku odgovornost i potanko morao položiti račun te globu platiti kesom i životom. 
61. Koibi Knez, za mito, iali Priateijstuo, otio priskoçiti, iednoga, à nadrugoga zapouidit, zaçuusi Gospoda, bude dobio paliçije imaho, ij birsag platio, zasto Knez mose szuakome prauiçno zapouidit, ij sudit, Vechie achobi iedan trudan dosaho sputa, tako onda mose prischoçiti doklam trudan opoçine ter poslia da izuarsi.

62. Koi Knez naurime nebi donesaho, maslo, ij Kudiu, da se tach, ij ostala tomu nauadna po starom zakonu, ij obiçaiu, bude tesko paliçije imaho za gniegon plachiu neposlusauusi stomuse zapouida, ij dusnost iest gniegoua.

63. Da szuako Selo po starom nauadi, ij obiçaiju, imade za szue Blagdane loua nositi, Gospodi ù Grad, achoij nebi mogli zuiuine ulouiti, tako pitomine doniti zasto Knez namisto Sela bude odgouara tescho.

64. Koi doijde, ter Gospodi Kazuije, daije nikoi desetinu zathaio, onomu odnese çetuarti dio dati Gospoda, uise toga nechie pripouidan biti, nitiga kaziuat drugima od kogasu Gospoda izuzuali, da szuaki to dobro upamti.

65. Koi Gospodi donese glasz, daie koije Sello ribu, iali rake drugamo uozilo prodauati, bude ono Sello birsaga Gospodi platilo tri forinta, à onomen koi prokase, budu dana tri mariasa, zasto priase mose, Varos domachi slusiti poslia druge strane.
61. Koji bi knez zbog mita ili prijateljstva htio preskočiti (osloboditi od obveza) jednoga, a drugome zapovjediti, saznaju li to gospoda, bit će dobro izbatinan i platit će globu jer knez mora svakome pravedno zapovijedati i suditi, posebno ako bi jedan trudan s puta došao, takvoga onda može preskočiti dok ne otpočine i pustiti da poslije izvrši.

62. Knezu koji na vrijeme ne bi donio maslo i kudjelju, ii ostalo tome slično, po starome zakonu i običaju, ima dobiti teške batine za svoju plaću jer nije slušao što mu se zapovjedilo i što jest dužnost njegova.

63. Svako selo ima po staroj navadi i običaju za sve blagdane ulov nositi gospodi u grad, a koji ne bi mogli divljač uloviti, donijet će domaće životinje, zašto punu odgovornost snosi knez u ime sela.

64. Koji dođe te gospodi kaže da im je netko zatajio desetinu, tomu će gospoda dati četvrti dio, više neće biti spominjan, niti će se kazivati drugima od koga su gospoda saznala, da svaki to dobro upamti.

65. Koji gospodi donese glas da je neko selo ribu ili rakove drugamo vozilo prodavati, to će selo gospodi platiti tri forinte globe, a onomu koji prokaže bit će dana tri marijaša (novac), zato što se najprije mora domaća varoš opskrbiti, a poslije druga mjesta. 
66. Vise toga kada Bog srichiu dade, da uloue Gospodi da ni koliko na Kuigniu, stobi bilo spodobno à drugo slobodno prodauati, cinom kakose bude moglo tolikoier drugo szuasto, sto bise imalo od siromastua, za prodauati, dase mose ista zapomochi.

67. Koia Sella imadu Vodenice, da mogu znati, nauadu, ij dusnost, od reçeni, Gospodi zemanschom, nagodiste dauati, po iedan zlat dukat, to ide od temeja, ij summe, koiu siku za potriboschie od reçeni uodenicza, kuchia, kola, saszuom ostalom mestriom, à to buduchi dusnost po szuiu Vilaieti Cesarstuua.

68. Da szuako Sello, Çobane, iati Çordase, imade darsati, kakonose darse po ostali Vilaeti, ter da pasu Goueda, Kognije, ij ostalu marù uschupa, ter dase nebi steta çinila, ij achobise uçinila da reçeni Çobani imadu naplatiti, a Sella gnima spodobne plachie dauati, kakose budu mogli pogoditi sgnima, zasto dicu posiaiuch, nista drugo, nechie igrati se à marua kamoiom drago da ide, ioste uise toga gdi mogu dignia, iali bundeua uchrasti, ter pechi ij sgnimase zabauiti, à ne maruu çuuati poslia Dicu çinit raditi pri Kuchi, nikoije, presti, nikoije daruaçz doniti, szuakom dobar Gospodar iali domachin nachi gdie posla pri szuoiem siromastu.

69. Da niedan Paor iali Kmet, nemose pribirati sella iz iednoga, u drugi ili stauati nechie szuaki szuoga Sella çuuati, kakonosu mogli gnioni Roditei stati, tacho ij onni mogu pribiuati, u szuome obiçaiu Oçinstua staroga.
66. Povrh toga, ako Bog da dobar ulov, neka za gospodsku kuhinju ostave onoliko koliko se pristoji, a drugo slobodno prodaju po cijeni kako se bude moglo, također i sve drugo što bi se moglo prodati kako bi se imali čime u siromaštvu pripomoći.

67. Koja sela imaju vodenicu, neka znaju za navadu i dužnost da, od spomenutoga, gospodi zemaljskoj imaju godišnje davati jedan zlatni dukat, i to zato što sijeku šume za potrebe vodenice, kuće, kola, i svih ostalih poslova. I zato jer je to dužnost u svim pokrajinama carstva.

68. Svako selo ima držati čobane ili čordaše, kao što se drže po ostalim pokrajinama, da pasu goveda, konje i ostalu marvu skupa, pazeći da ne bi došlo do štete, a ako bi nastala, spomenuti ju čobani imaju platiti, a selo njima dolične plaće davati, već kako se budu pogodili s njima. Djecu ne slati jer ona ništa drugo neće raditi nego igrati se, a marva kamo joj drago ići, a povrh toga će, gdje mogu, dinja ili bundeva ukrasti i peći i njima se zabaviti, a ne marvu čuvati. Djecu treba uposliti pri kući, jedna nek predu, druga drva donose, svakom će dobar gospodar ili domaćin već negdje naći neki posao.

69. Nijedan seljak ili kmet ne može mijenjati selo, iz jednoga u drugo ići stanovati, već svaki svoje selo čuvati, kako su mogli njihovi roditelji ostati, tako mogu i oni prebivati u svome, po starom očinskom običaju. 
3.

\section{Optužbe biskupa Bakića na račun đakovačkih franjevaca}

\section{Iz Istrage koju je zapovjedio isti protiv mp. đakovačkih franjevaca pod prisegom iznuđenih očitovanja izlazi:}

(1) da se poštovani franjevci oblače u muška i ženska odijela i plešu javno sa ženskim svijetom (spolom);

(2) da protiv biskupova oprosta daju da se slobodno radi na blagdan sv. Jurja, a to isto prenose dan kasnije na dan sv. Alberta (Adalberta);

(3) da p. Porcelović odbija sudjelovati na procesiji Tijela Kristova govoreći da on na nju nije obvezatan, iako ima župu u biskupovoj dijecezi;

(4) da je isti pater pokraj oltara Blažene Djevice Marije postavio okove nekog koji je pobjegao biskupovu zapovjedniku grada, tumačeći narodu da je to zarobljenik iz Bosne;

(5) da je pater đakovački vikar s oltara rekao da ispričava one koji traže oprost od biskupa, govoreći, mi smo oni koji mogu podijeliti oprost;

(6) da je p. Luka Brođanin pohodio generala Petrascha tražeći da makne straže slugu (vojnika) Presvijetloga biskupa od upravne zgrade;

(7) da su vjenčali sina nekog mlinara bez prethodnih (ženidbenih) navještaja;

(8) da su za vrijeme Jubileja odbili ispovijedati prije nego što im grad ne donese pruća i kolaca te povežu ogradu (plotove);

(9) da brane ljudima slušati biskupovu propovijed, veleći: više vrijedi propovijed jednog jednostavnog svećenika nego sadašnjeg biskupa koji ne zna ni služiti misu ni razlikovati bijelo od crnog;

(10) da je p. Luka izjavio da se ni na koji način ne podlaže biskupovoj jurisdikciji, osim ispitu;

(11) da je P. Garčinac kod biskupskog stola pričao kako je podijelio posljednje pomazanje nekoj inače zdravoj ženi za tri lakta platna (tkanine);

(12) da je p. propovjednik u crkvi sv. Bartola proglasio narodu oprost bez biskupova dopuštenja;

(13) da tko bi htio raditi na blagdane neka ne ide na konzultacije k biskupu nego k njima (franjevcima);

(14) da su u Rimu inzistirali da budu oslobođeni od biskupove duhovne jurisdikcije i da se za ove krajeve postavi drugi delegat;

(15) kažu, da je biskup lud i ne zna što radi, pa iako mu je zaštitnik pečujski biskup, koji se pravi carevim bratićem, ipak ne bi trebao nama škoditi;

(16) da ispovijedaju bez jurisdikcije primljene od biskupa. ${ }^{100}$

${ }^{100}$ J. STANIĆ, Brevis Notitia, 68.-70. 
4.

\section{Optužbe i žalbe gospodina bosanskog biskupa na generala u Osijeku ${ }^{101}$}

1. Osječka kuća predšasnika sadašnjeg biskupa u kojoj do danas stanuje sudski preslušatelj i imanje u Gornjem gradu koje je u posjedu g. Kalleneka, usprkos milostivom rješenju uzvišenog Ratnog vijeća i Visoke komore usprkos tolikim podnesenim zahtjevima, nikako se nisu mogli dobiti natrag.

2. Iako je husar bio uhvaćen u krađi biskupskog sijena, gospodin osječki General nije dao nikakvu nadoknadu, a sijeno koje je pokošeno na biskupskoj livadi zvanoj Beketinci, i sijeno što ga vojnici još trebaju pokositi, naredio je da čepinski husari imaju odvesti u njegovu štalu. Svojim je pak podanicima zabranio da u gradu Đakovu smiju izgraditi tako velik most, kao što je to g. Biskup radi javnih potreba naredio.

3. Gospodin osječki General na svoju ruku uzima takozvane husare od biskupskih podanika, koji iako posjeduju biskupske zemlje i livade, ne daju biskupu ništa, a još manje caru i Crkvi, ali niti bilo kome rabote i prijevoz (kola), nego slobodno koriste biskupske šume, polja, livade, ogranke, podižu mlinove, krčme, tržnice, mesnice, vinograde i druga mjesta koja kupuju od biskupskih podanika i oslobađaju ih od davanja bilo kakve desetine ili podavanja. Biskupske seljake koji su dužni služiti oslobađaju od svih obveza, i braću tako i njihove roditelje kao da oni na takve službe nikako nisu obvezani. Što je najgore za g. Biskupa, njima je dopušteno da imaju jedanaest krčmi u gradu Đakovu, a zemaljski gospodar ima samo jednu. A dužnost tih husara ujutro se sastoji da služe gosp. osječkom Generalu u štali, vrtu. Jednako tako gospodin General na svaki način želi da udovice, ako kojoj umre muž, uživaju slobodu kao da im muž živi.

4. G. biskup je naredio da se valpovačkim podanicima koji su boravili na biskupskoj zemlji, nakon što se vrate na valpovačko Dobro, njihovo sjeme sekvestrira, dok biskupski podanici ne budu vraćeni iz valpovačkih zemalja. Ali nakon što je inspektor Dobra Valpovo, pred gospodinom Generalom izvršio uvid, sekvestrirano sjeme vojska je oduzela s biskupskih zemalja, a biskupski podanici nisu vraćeni.

5. Gospodin General je izdao naredbu za Slavoniju, da se nitko pod (prijetnjom) kazne gubitka robe ne usudi ići na dane đakovačkog sajma, koji se obdržavaju od pamtivijeka. Zastavnik đakovačkih husara, narodski zvan Barjaktar Mato, proglasio je da su osječka gospoda odredila da sve biskupske sluge moraju

${ }^{101}$ HR-NAĐ, fond Bakić, kut. Bakić, Querelae contra Dnum Generalem Essekiensem 1728. Riječ je o generalu Oduyeru. 
shvatiti, ako gospodin biskup zapovjedi da oni hvataju ljude koji su ga tužili u Osijek, i tako biskupski podanici neka sluge vezane za konje, i samog biskupa dovedu u Osijek /:ako iziđe u pomoć:/. A njemačko poručništvo bilo je dano vojsci na pomoć, da one podanike koje g. biskup zbog zločina naredio staviti u okove, odmah prihvati.

6. Pavao Bošnjak, biskupski podanik, koji se proglasio vladarom (kraljem) ovog područja, i koji je podigao već drugu bunu, huškao je Budrovčane da idu u Osijek tužiti biskupa, a nakon što su se Budrovčani vratili iz Osijeka, njihov je sudac Blaž naredio je da se po svim selima razglasi da svi podanici idu tužiti biskupa u Osijek, inače će g. General zapovjediti da se svima neposlušnim podanicima, ne samo odsijeku nos i uši, nego će narediti da se zatvore.

7. Ženu nekoga obješenoga, koji je obio carsku blagajnu, i njegove sinove g. General je oslobodio od svih davanja i tereta, i njoj je prepustio jednu gostionicu. Isto tako kad su graničari na rijeci Savi počeli graditi vodenicu - da biskupske podanike prisile ići onamo - isti graničari su srušili jednu vodenicu na rijeci zvanoj Biđ, ata je na biskupskom području bila još u tursko vrijeme.

8. Kad je g. Biskup uređivao kroz guste šume na milje dugačke javne puteve, i za vrijeme božićnih blagdana boravio kod kuće, da ne bi među ljudima došlo do kakve nesloge, ostavio je dva carska mušketira. Na njih su navalili podanici i njih su bez sumnje da ne bi u pola noći pobjegli, zamijenili, usuđujući se još u prisutnosti biskupa tvrditi da oni za to nisu ništa krivi. Kad su neki od njih prepoznali iz prethodne bune, gospodin biskup ih je uhitio i za kaznu poslao u Osijek, no gospodin general ih je bez ikakve kazne i bez biskupova znanja otpustio slobodne.

9. Ako se prema zapovjedi g. Generala biskupov podanik šalje u Osijek u zatvor, pa se ustanovi da je nevin, uhićenika treba osloboditi, a onoga koji je krivo optužio niti se ne spominje. Ako se od g. Generala traži pravda ili neka nadoknada, nju g. Biskup ne može dobiti, a pogotovo kakav odgovor. Iako se g. biskupu češće obećavalo, ako on želi imenovati neke službenike koji bi revidirali neke nejasne granice između g. biskupa i dugih susjeda, to se dosad nikada nije ispunilo.

10. G. General želi zaštićivati oce franjevce, a pogotovo župnike koje je biskup zbog župničkih službi suspendirao i štititi protiv duhovnih odredaba g. biskupa. Namjeravao je spriječiti i posvetu kapucinske crkve u Osijeku, usprkos tome što su spomenuti oci kapucini od primasa Uzvišenog Ugarskog kraljevstva već imali dopuštenje /: pod čijom je jurisdikcijom ta crkva:/ da se (posveta) može povjeriti bilo kojem katoličkom biskupu.

11. G. General je g. biskupu koji je htio kupiti kuću u Osijeku za sebe i za svoje nasljednike /: jer ona kuća prethodnika njemu još nije vraćena:/ govorio da 
on bez dopuštenja uzvišenog Ratnog vijeća to ne može dodijeliti, a šizmatički je metropolit u Donjem gradu dobio mogućnost kupiti kuću. Osim toga, branio je jednog šizmatičkog biskupa koji je na Dobru bosanskog biskupa za sebe skupljao novac i tražio priloge, gdje siromašni ljudi jedva mogu dati Njegovu veličanstvu redoviti namet. I zbog toga je gosp. biskup zapovjedio da šizmatika obavijeste da to prestane i da odande ode, a kad on nije htio, uzeo mu je konje. No prema nalogu g. Generala odmah mu je vratio, zbog čega je protiv svih prava g. Biskup bio pozvan da se pojavi na sudu.

12. Kada su oci franjevci tajno odnijeli mrtvo tijelo biskupskog sluge, a biskup htio da ga sahrane dvojica kapelana, isto tako kad su biskupski kapelani u franjevačku crkvu željezom otvorili, spomenuti oci su dijelom poderali a dijelom oteli štolu i roketu. A nakon što je stigao biskup, ne samo da su vrata crkve bila zatvorena nego su ti oci carske husare nahuškali da kamenuju g. biskupa. Da smiri tu gomilu, priskočio je u pomoć carski vojni zapovjednik s razvodnikom i s nekoliko pridošlih vojnika, Gospodin General je zapovjedio da se odvedu u zatvor rečeni zapovjednik i razvodnik. Je li ono što je general Njegova Veličanstva (učinio?) bilo dolično, prepušta se sudu svakog pojedinca. Još bi se moglo mnogo govoriti o Generalovim ekscesima. Ali budući da se to ni najmanje ne tiče optužbi gospodina Biskupa, namjerno se ispuštaju.

Da je sve napisano istinito, svjedočimo dotičući svoje svećeničke grudi.

L.S. P. Ivan Pavao Messarius, mp.

L.S. P. Marinus Paluh, mp. ${ }^{102}$

5.

\section{Slučaj jednog sprovoda}

Mi, potpisani kao očevici svjedočimo, iako su Poštovani Oci Đakovački Franjevci znali da Presvijetli i Preuzvišeni Gospodin, Gospodin Biskup Petar Bakić de Lack naređuje da njegove sluge sahranjuju njegovi kapelani, usprkos tome zvonili su za pokojnoga Stjepana Lukmara, slugu Presvijetloga i Preuzvišenoga Gospodina i prije dvadeset i četiri sata poslije njegove smrti prenijeli u svoju crkvu da ga sahrane. Čuvši to Presvijetli i Preuzvišeni Gospodin, Gospodin Biskup poslao je dva svoja kapelana u crkvu spomenutih otaca Franjevaca, da preuzmu i sahrane tijelo pokojnika. Stoga, kad su oo. Franjevci vidjeli, da kapelani Presvijetlog i Preuzvišenoga Gospodina Biskupa žele ući u crkvu, da sahrane mrtvaca, odmah su je zatvorili, a potom su iz samostana izašli p. Petar Đakovac gvardijan mjesta, i p. Grgur iz Našica, vikar, koji su kapelane Presvijetloga i Preuzvišenoga biskupa koji su stajali pred nji-




hovom crkvom htjeli otjerati kući /: to se dogodilo 19. rujna 1747./ gurnuvši Preč. gospodina Martina Paluha, ali budući da mu ništa nisu mogli učiniti, iz samostana su izašli i o. Antun iz Budima, lektor filozofije, o. Franjo iz Pečuha propovjednik, o. Franjo Lošić, fra Nikola iz Gradiške, o. Se...(?) iz Velike, fra Bernardin iz Osijeka, o. Petar iz Požege, među njima prvi o. Franjo zajedno sa o. gvardijanom i p. vikarom nasrnuli su na Martina Palucha i štolu koju je imao oko vrata poderali na tri komada /: od kojih jedan komad još danas imaju u rukama:/ i roketu i jedan rukav odijela. Kad se to dogodilo napali su gospodina Ladislava Bresnitki i štolu koju je imao oko vrata oteli i do sad je nisu vratili. Budući da je Presvijetli i Preuzvišeni Gospodin, Gospodin Biskup sve to promatrao sa svog prozora, uzeo je sa sobom pet vojnika i oce franjevce blago hrabreći nagovarao da otvore crkvu, da se pokojni sahrani. Ali oni pozivaju se na svoje pravo su bijesno vrijeđali. Zbog toga je Presvijetli i Preuzvišeni Gospodin, Gospodin Biskup htio na silu otvoriti crkvena vrata i kad su već franjevci vidjeli da želi na silu ući pater vikar je imajući sjekiru pod pazuhom što su svi vidjeli izgovorio je slijedeće riječi $\gg$ pa ako trebam i umrijeti «. Zatim su svi franjevci jednoglasno povikali »udri udri « (na hrvatskom) što znači udri. Kad su to čuli... gotovo su svi vojnici ovoga grada Djakova izašli, da se ne bi dogodilo kakvo zlo. I da oni nisu izašli Presvijetlog i Preuzvišenoga gospodina Biskupa bi kamenovali ne samo carski Husari nego i franjevci. Za vjerodostojnost u Đakovu 12. lipnja 1728.

Ivan Pavao Messarius, svećenik, vlastitom rukom

brat Danijel Bostor Fertetić reda svetoga Augustina kod svetog Marka u šumi Dragotin eremita vlastitom rukom 


\section{STARINSKE I STRANE RIJEČI}

\begin{tabular}{ll} 
arestan & bačenu zatvor \\
baćiluk & radovi u ime desetine \\
bandur (pandur) & vojnik \\
bašćolan & vrtlar \\
begluk & zemliǰšni posjed koji pripada begu; \\
& rad za bega; također državna carska \\
biršag & globa blagajna (i sam rad za državu ili bega) \\
boljuch & gomila, imanje \\
čair & livada \\
čordaš & čuvar krava \\
dželat & krvnik \\
enkar & krvnik \\
fati & prevoženje drva \\
foruna & peć \\
fospont & drveni mostovi \\
kasap & mesar \\
klafteri & pravilno naslagana drva, hvati \\
krečara & vapnara \\
marijaš & ugarski novac \\
marše & živinče \\
meštrija & obrt, vještina \\
obataliti & zapustiti, opustošiti \\
palić & palica, batina \\
palisata (palisada) & ograda od kolaca \\
pečat & potpis \\
sesija & zemljišni posjed, imanje \\
šaraluk & desetina \\
šurbati se & prostituirati se \\
talir & novčić \\
trgati & brati \\
varoš & grad, trgovište \\
vilajet & pokrajina, oblast \\
žgati & peći, spaliti \\
& \\
\hline &
\end{tabular}




\title{
PETAR BAKIĆ - A BISHOP AND A LANDOWNER (1716-1749)
}

\author{
Marin SRAKIĆ*
}

Summary: 300 years ago, in 1716, Petar Bakić was appointed the Bishop of Bosnia or Đakovo, a priest of the (Arch)diocese of Split, a hardworking missionary of the Pannonian-Slavonian region, the »elected bishop of Srijem《 (electus Sirmiensis). When Bakic took over his ministry, the traces of Turkish destruction were still visible in the diocese. That is why he wholeheartedly began to renovate the diocese beginning with the extension of the cathedral church, through the renovation of some parish churches, the acquiring of church furniture, etc. The diocese was small, only four parishes under pastoral care of the Franciscans of the Province of Bosnia Srebrena. His arrival marked the organized economic amelioration in all areas, such as viticulture, farming, livestock breeding, etc. Because of his fiery temper, the bishop often came into conflict with his surroundings: the Franciscans, the Chamber supervision in Osijek and the subjects. The Franciscans had defended their pastoral rights and invoked their merits, the military authorities had violated in all possible ways Bakićs rights as a landowner, but also as a bishop, and the subjects complained to various levies and hard work in the landscaping of the estate. After countless lawsuits and accusations from both sides, the War Council under the presidency of Eugene Savoy, and with the consent of the imperial court, had sequestered bishop Petar Bakić, forbidding him to enter the area of his diocese. Much of what he in his diligence had planted and built was damaged or destroyed during his absence. When he returned to the diocese with the pardon of Empress Maria Theresa, he found a desolation that he could not bear and returned to his estate in Križovljan near Varaždin, where he died in 1749. He was buried in the local church, but the location of his grave is unknown.

Keywords: Bakić, missionary, Bosnian Diocese, Franciscans, Chamber supervision, manorial estate, economic amelioration, viticulture, legislator, sequester.

\footnotetext{
* Mons. Marin Srakić, Ph. D., Archbishop emeritus of Đakovo-Osijek, Strossmayerov trg 6, 31400 Đakovo, Croatia, marin.srakic@djos.hr
} 